\title{
Molecular ontogeny of larval immunity in European eel at increasing temperatures
}

Running title: Immunity in European eel larvae

Joanna J. Miest ${ }^{1,2, *}$, Sebastian N. Politis ${ }^{3, \neq}$, Mikolaj Adamek ${ }^{4}$, Jonna Tomkiewicz ${ }^{3}$ and Ian A.E. Butts $^{3,5}$

${ }^{1}$ Evolutionary Ecology of Marine Fish, GEOMAR Helmholtz Centre for Ocean Research, 24148 Kiel, Germany

${ }^{2}$ Department of Life and Sport Sciences, University of Greenwich, Chatham Maritime, Kent, ME4 4TB, UK

${ }^{3}$ National Institute of Aquatic Resources, Technical University of Denmark, 2800 Kgs. Lyngby, Denmark

${ }^{4}$ Fish Disease Research Unit, Centre of Infectious Diseases, University of Veterinary Medicine Hannover, 30559 Hannover, Germany

${ }^{5}$ School of Fisheries, Aquaculture and Aquatic Sciences, Auburn University, Auburn, Alabama, 36849, USA

$\ddagger$ These authors contributed equally to the manuscript

* Corresponding author's email: j.j.miest@gre.ac.uk 


\begin{abstract}
:
Temperature is a major factor that modulates the development and reactivity of the immune system. Only limited knowledge exists regarding the immune system of the catadromous European eel, Anguilla anguilla, especially during the oceanic early life history stages. Thus, a new molecular toolbox was developed, involving tissue specific characterisation of 3 housekeeping genes, 9 genes from the innate and 3 genes from the adaptive immune system of this species. The spatial pattern of immune genes reflected their function, e.g. complement component $c 3$ was mainly produced in liver and $i l 10$ in the head kidney. Subsequently, the ontogeny of the immune system was studied in larvae reared from hatch to first-feeding at four temperatures, spanning their thermal tolerance range $\left(16,18,20\right.$, and $\left.22^{\circ} \mathrm{C}\right)$. Expression of some genes (c3 and igm) declined post hatch, whilst expression of most other genes $(m h c 2, t l r 2, i l 1 \beta, \operatorname{irf} 3, \operatorname{irf} 7)$ increased with larval age. At the optimal temperature, $18^{\circ} \mathrm{C}$, this pattern of immune-gene expression revealed an immunocompromised phase between hatch $(0 \mathrm{dph})$ and teeth-development $(8 \mathrm{dph})$. The expression of two of the studied genes (mhc2, lysc) was temperature dependent, leading to increased mRNA levels at $22^{\circ} \mathrm{C}$. Additionally, at the lower end of the thermal spectrum $\left(16^{\circ} \mathrm{C}\right)$ immune competency appeared reduced, whilst close to the upper thermal limit $\left(22^{\circ} \mathrm{C}\right)$ larvae showed signs of thermal stress. Thus, protection against pathogens is probably impaired at temperatures close to the critical thermal maximum $\left(\mathrm{CT}_{\max }\right)$, impacting survival and productivity in hatcheries and natural recruitment.
\end{abstract}

\title{
Key words (3-6):
}

Fish Larvae; Innate Immunity; Anguilla anguilla; Early Life History, Gene Expression; Aquaculture; Climate change

\section{Introduction:}

With more than 34,000 species, teleost fish represent the largest class of vertebrates [1]. This diversity reflects their successful adaption to a great variety of aquatic environments. However, common to most species is an elevated natural mortality during early life [2]. Thus, subtle differences in survivorship can cause large differences in annual offspring production [3]. This is especially important for species that may spawn only once in a lifetime, such as the European eel (Anguilla anguilla, Linnaeus 1758), as survival during early-life represents a substantial component of variation in lifetime fitness. An increased understanding of the physical and biological factors that influence mortality rates during these 'critical' developmental stages can enable aquaculture 
hatchery production, enhance recruitment predictions for fisheries, and aid in the conservation of this critically endangered species [4].

Teleost fish possess both the innate and adaptive arm of the immune response, characteristic to higher vertebrates [5]. However, evidence has accumulated that newly hatched fish larvae are highly sensitive to pathogens as their immune system is not fully developed [6]. Marine fish larvae are particularly vulnerable to pathogen-induced mortality as it can take up to three months until their immune response is fully functional [7]. During this time, the larvae solely rely on the innate arm of the immune system, which acts in a non-specific manner. During the first stages of larval development (i.e. hatching, mouth opening, first-feeding) exposure to pathogens intensifies [8]. Knowledge of the development of the immune system is hence needed to design preventative methods against pathogens such as the anguillid herpesvirus 1 (AngHV-1) and the parasite Anguillicoloides crassus, which pose an important threat to the European eel [9], in order to prevent losses in forthcoming aquaculture hatcheries. The European eel is a commercially high-value fish species with a long tradition in European fisheries and fish farming. Recruitment and stock size of European eel have decreased substantially in the last decades [10] and a European-wide management strategy is being implemented, while efforts to establish hatchery technology for this species are ongoing [11,12]. However, up-to-date farming as well as restocking of European eel relies on wild-caught juveniles as the life-cycle has not been closed in captivity. It is therefore vital that breeding-technologies and hatchery techniques are being established. Recent advances have enabled the stable production of eggs and larvae, which allow the development and optimisation of hatchery protocols $[12,13]$.

During development organisms are influenced by extrinsic factors (e.g. temperature, pathogens), intrinsic factors (e.g. genetic makeup), and their associated interactions $[14,15]$. Temperature is one of the main factors influencing marine ecosystems, as it defines the geographical distribution of populations and affects the physiology of individual organisms at all life stages [16]. Furthermore, physiological processes, and therefore development and survival, in ectothermic organisms are generally controlled by the environmental temperature [17]. Here, early life history stages are known to be particularly sensitive to temperature as they have a narrower thermal tolerance window than juveniles or adults and thus are more profoundly affected by even minor temperature changes and short heatwaves [18]. Moreover, temperature is a fundamental modulator of the immune system of fish [19] and has been shown to affect immunity during fish 
early life history [20]. The consideration of temperature as an immunomodulatory factor is therefore not only important in the development of hatchery technology of a species such as the European eel in order to optimise offspring rearing protocols, but also in the light of environmental changes in the natural habitat of the larval stages of this species. Here, warming temperatures of the ocean may influence the recruitment of the critically endangered European eel $[21,22]$.

Eels, i.e. Anguilliformes, are basal bony fish (Teleostei) which belong to the ancient superorder of Elopomorpha, at the phylogenetic basis of Teleostei [23]. The current knowledge of eel immunity has recently been reviewed [24]. Whilst the immune system of fish is well studied in some model species, very little research has been conducted regarding the immune system of Elopomorpha with their unique leptocephalus larvae. Research conducted on the immune system of European and Japanese eels (A. japonica) has up to date focused on the cellular innate immune response to infections and have rarely involved molecular studies [24]. For example, in Japanese eel it has been shown that some immune factors (i.e. lectin) are present 8 days post-hatch (dph; rearing temperature unknown), whilst the appearance of most immune organs occurs late during larval development [25]. In this study, we aimed to elucidate certain aspects of the development of the immune system in European eel larvae. Specifically, as part of the innate immune system we investigated two complement components (c3 and $c 1 q c)$, which aid microbial killing, phagocytosis, inflammatory reactions, immune complex clearance, and antibody production (reviewed by [26]). Moreover, we monitored gene expression of the antimicrobial protein C-type lysozyme (lysc), the cytokines interleukin $10(i l 10)$ and $1 \beta(i l 1 \beta)$, as well as tumor necrosis factor alpha (tnf $\alpha)$. Cytokines aid both the innate and the acquired immune system by interacting with cells, ligands, and receptors to activate cell-mediated immune responses [27]. IL-10 is an anti-inflammatory cytokine whilst IL-1 $\beta$ expression leads to activation of lymphocytes and synthesis of acute phase proteins and thus activation of the complement system [28]. Furthermore, TNF- $\alpha$ is involved in the control and local restriction of infection. In lieu of measuring antiviral type 1 interferon expression, we analysed interferon regulating factors 3 and 7 (irf 3 and $\operatorname{irf} 7$ ) as they have previously been described for European eel [29]. Additionally, we analysed the expression of a pathogen recognition receptor, the toll like receptor 2 (tlr2), which is suggested to recognize bacterial and fungal pathogens in eel [30], while the adaptive immune response was studied using the major histocompatibility complex II ( $m h c 2)$, immunoglobulin M (igm) and the cluster of differentiation 3 $(c d 3)$. Here, MHC II is responsible for the presentation of antigens to adaptive immune cells and thus the initiation of an adaptive immune response. This recognition ultimately leads to the 
destruction of the pathogen through the immune response [28]. Moreover, IgM is the first immunoglobulin to be produced after activation of B cells and can then interact with the complement component $\mathrm{C} 1$ to activate the classical complement pathway [28]. Last, CD3, a protein complex, associated to the T-cell receptor and acting as co-receptor, is involved in the activation of T-cells. Together, these immunological insights may be critical to close the life cycle in captivity for this commercially high-value fish species within aquaculture, and to better understand potential impacts of ocean warming on early life stages in nature.

This study therefore aimed to i) develop tools to specifically study innate (i.e. complement components, antimicrobial peptides, cytokines) and adaptive (i.e. MHC II, immunoglobulin M) immunity in European eel; ii) shed light on the molecular ontogeny of their immune system during early larval development; and finally iii) investigate the interaction of immune gene expression with temperature during early life history.

\section{Material and methods:}

In order to fulfil the above aims we carried out three independent studies. To develop the molecular toolbox to study immune related genes, we characterised the tissue specific expression of the studied genes (see 2.1) and their regulation in response to an AngHV-1 infection (see 2.2). For the purpose of studying thermally modulated immune gene ontogeny, we carried out a study on eel larvae, which analysed immune-related gene expression every 2 dph at 4 different temperatures (see 2.3). In all studies, gene expression was analysed using molecular methods (see 2.4).

\subsection{Generation of tissue library from farmed immature eels}

The tissue specific expression of the studied immune genes was investigated using three immature female European eels at the yellow eel stage raised from the glass eel stage to a size of 58 $\pm 1.6 \mathrm{~cm}$ and weight of $470 \pm 39.7 \mathrm{~g}$ at a Danish commercial fish farm (Stensgård Eel Farm A/S). The eels were euthanized by submersion in an aqueous solution of ethyl p-aminobenzoate (benzocaine) at $20 \mathrm{mg} \mathrm{L}^{-1}$ (Sigma-Aldrich, Missouri, USA) and organ tissue samples dissected from hind-gut, gills, head kidney, kidney, liver, skin, spleen, whole brain, heart, and muscle. Samples were stored in RNA-later at $-80^{\circ} \mathrm{C}$ until further use. For further processing see 2.4. 


\subsection{AngHV-1 infection of Juvenile European eel tail explants}

In addition to the tissue specific expression, we characterised the response of the targeted immune genes to AngHV-1 infection. The alloherpesvirus AngHV-1 is a highly virulent infection agent and considered the most significant viral threat to the eel population. The virus causes extensive necrosis in the gills as well as necrotic lesions in the skin [31]. Here, we used an in vitro model to study the immunological response to an AngHV-1 infection in compliance with the $3 \mathrm{R}$ rule. As the in vivo infection system is not well established yet for AngHV-1 in European eel, we conducted the infection using explants of the tail tissue. Tail tissues ( $10 \mathrm{~mm}$ of the body end) were sampled from 10 euthanized (with $0.5 \mathrm{~g}^{-1}$ of MS-222) European glass eels during routine health checks at the Veterinary University Hannover, Germany. The fish from which the explants had been collected were confirmed to be AngHV-1 negative by qPCR described earlier [9]. The explants were collected into PBS supplemented with $10 \mathrm{IU} \mathrm{ml}^{-1}$ penicillin, $100 \mathrm{mg} \mathrm{ml}^{-1}$ streptomycin, $100 \mathrm{mg} \mathrm{ml}^{-1}$ gentamycin, and $1 \mathrm{mg} \mathrm{ml}^{-1}$ amphotericin B (all Sigma), and thereafter placed on ice. Explants were placed individually into the wells of 24 well tissue culture plates and $1 \mathrm{ml}$ of culture medium (medium 199 supplemented with $20 \% \mathrm{FCS}, 10 \mathrm{IU} \mathrm{ml}^{-1}$ penicillin, $100 \mathrm{mg} \mathrm{ml}^{-1}$ streptomycin, 100 $\mathrm{mg} \mathrm{ml}^{-1}$ gentamycin and $1 \mathrm{mg} \mathrm{ml}^{-1}$ amphotericin B [Sigma]) was added to each well. Explants were incubated at $25^{\circ} \mathrm{C}$ in a humidified atmosphere containing $2 \% \mathrm{CO}_{2}$. After $1 \mathrm{~h}$, half of the explant cultures $(n=5)$ were randomly infected by adding $10 \mu \mathrm{l}$ of AngHV-1 virus suspension [32]. The final concentration of the virus was $5 \times 10^{5} \mathrm{TCID}_{50} \mathrm{ml}^{-1}$. Controls received $10 \mu \mathrm{l}$ of uninfected medium. After $48 \mathrm{~h}$ the explants were placed in RNA-later and stored in $-80{ }^{\circ} \mathrm{C}$ until further processing.

RNA was extracted from the tip of the tail as described above and diluted to a common

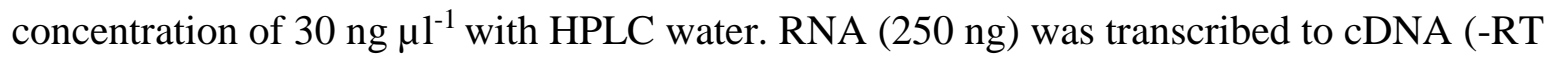
controls were included) and expression in these samples were analysed using the qPCR Biomark ${ }^{\mathrm{TM}}$ HD system (Fluidigm) based on 96.96 dynamic arrays (GE chips) as described below in section 2.4. Further analysis of gene expression was carried out according to the $2^{-\Delta \Delta \mathrm{Ct}}$ method, in relation to the non-infected control [33]. Gene expression for these samples was normalised against the geometric mean of $\operatorname{rps} 18$ and efl $(=\Delta \mathrm{ct})$ as these genes showed the highest stability (see 2.4 ). 


\subsection{Experimental broodstock management and offspring production}

Female silver eels were obtained from a freshwater lake, Vandet Sø, Denmark. Male eels were obtained from Stensgård Eel Farm A/S. Females used for experiments $(n=4)$ had a mean $( \pm$ SEM) standard length and body weight of $65 \pm 4 \mathrm{~cm}$ and $486 \pm 90 \mathrm{~g}$, respectively. Male eels $(\mathrm{n}=$ 11) had a mean ( \pm SEM) standard length and body weight of $40 \pm 3 \mathrm{~cm}$ and $135 \pm 25 \mathrm{~g}$, respectively. Experiments were conducted at a DTU Aqua research facility located at Lyksvad Fish Farm, Denmark. For detailed information on fish handling, maturation and strip spawning, as well as gamete collection and fertilisation see $[11,12,34]$. The experimental protocol for the study was approved by the Danish Animal Experiments Inspectorate, Ministry of Food, Agriculture and Fisheries (permit number: 2012-15-2934-00458). All fish were handled in accordance with the European Union regulations concerning the protection of experimental animals (EU Dir 2010/63).

\subsubsection{Experimental conditions}

Eggs from each female were fertilised by a milt pool from 4 males [11] to experimentally create four parental crosses. In total, 11 males were used. Within 30 min post fertilization, 500 floating zygotes per $100 \mathrm{~mL}$, with a mean size $( \pm \mathrm{SD})$ of $1.5 \pm 0.1 \mathrm{~mm}(\mathrm{n}=4$ females $)$, were distributed in replicated $600 \mathrm{~mL}$ flasks $\left[182.5 \mathrm{~cm}^{2}\right.$ sterile tissue culture flasks with plug seal caps $\left(\mathrm{VWR}^{\circledR}\right)$ ] [34]. Larvae were reared in thermal controlling incubators (MIR-154 Incubator, Panasonic Europe B.V.) at five temperatures $\left(16,18,20,22\right.$, and $\left.24 \pm 0.1^{\circ} \mathrm{C}\right)$, with a salinity of 36 ppt. Seawater was $0.2 \mu \mathrm{m}$ filtered, UV sterilized and supplemented with rifampicin and ampicillin (each $50 \mathrm{mg} \mathrm{L}^{-1}$, Sigma-Aldrich, Missouri, USA) [35]. Rearing of embryos and larvae took place in darkness, while handling and sampling was performed under low intensity light conditions $(<2.2$ $\mu \mathrm{mol} \mathrm{m} \mathrm{m}^{-2} \mathrm{~s}^{-1}$ ) [36]. Light and salinity levels as well as the temperature range were chosen to resemble the environmental conditions prevailing between 0 and 600 m's depth in the Sargasso Sea, i.e. the assumed spawning area of European eel, and to account for projected climate-driven ocean warming.

\subsubsection{Data collection}

For molecular analysis, $\sim 30$ larvae $(\times 2$ replicates $)$ from each temperature and parental combination were randomly sampled at hatch and every second day post-hatch until the corresponding first-feeding stage. As feeding trials were beyond the scope of this study, rearing was not conducted beyond these time points. Larvae were euthanized, using an aqueous solution of 
tricaine methane sulphonate (MS-222, Sigma-Aldrich, Germany) at 500 ppm, rinsed with deionized water, preserved in RNA-later (Qiagen, Germany), and kept at $-20^{\circ} \mathrm{C}$. No larvae hatched at $24^{\circ} \mathrm{C}$ and therefore this treatment was excluded from the statistical analysis.

\subsection{Molecular analyses}

The present study is part of a wider project in which various aspects of larval development were investigated. In this regard, various molecular pathways were investigated in the same larvae. Whilst this study focusses on the immune system, other studies have focussed on the expression of genes relating to stress and growth [34] as well as the thyroid hormone signalling pathway [37].

The present study took advantage of the assembly of the European eel genome [38] and obtained sequences (blastn) were checked for high similarity with other fish species (see supplementary material ST3). Primers (Table 1) were designed for real-time PCR with Primer3plus (http://primer3plus.com/). Molecular analysis was performed at GEOMAR, Helmholtz Centre for Ocean Research in Kiel, Germany. Total RNA from all samples was extracted using a combination of Tri-Reagent (Sigma-Aldrich, Germany) and the InviTrap ${ }^{\circledR}$ Spin tissue RNA MiniKit (Stratec) following the manufacturer's instructions. RNA concentration was determined by Nanodrop ND1000 (Peqlab, Germany) and normalized to a common concentration of $100 \mathrm{ng}^{-1} \mathrm{l}^{-1}$ with HPLC water. Consequently 680 ng RNA were transcribed with the Quanta qScript cDNA Synthesis Kit (QuantaBio, Germany) as described by the manufacturer including a genomic DNA wipe-out step [Quanta PerfeCta DNase I Kit (QuantaBio, Germany)]. Controls for gDNA efficiency were also included and cDNA was stored at $-20^{\circ} \mathrm{C}$ until further use.

Tissue specific expression was measured for 14 genes using the StepOnePlus qPCR system (Applied Biosystems, Germany). For this purpose, a mix of $2 \mu 1$ cDNA, 5x EvaGreen qPCR Mix Plus Rox (Solis Biodyne, Estonia), 2.5 pmol of each primer, and HPLC water was used in a total volume of $10 \mu \mathrm{l}$. The cycling conditions were $95^{\circ} \mathrm{C}$ for $10 \mathrm{~min}$, followed by 40 cycles of $95^{\circ} \mathrm{C}$ for $15 \mathrm{~s}$ and $60^{\circ} \mathrm{C}$ for $1 \mathrm{~min}$, followed by $95^{\circ} \mathrm{C}$ for $15 \mathrm{~s}, 60^{\circ} \mathrm{C}$ for $1 \mathrm{~min}$ and $95^{\circ} \mathrm{C}$ for $15 \mathrm{~s}$.

From all larval samples ( 4 crosses $\times 4$ temperatures $\times 2$ replicates) and the AngHV-1 infection samples, the expression of 14 genes $(r p s 18, t u b b$, efl $, c 3, c 1 q c, c d 3$, igm, irf3, irf 7, ill $\beta$, lysc, $m h c 2, \operatorname{tnf} \alpha, \operatorname{tr} 2$; Table 1) was analysed with three technical replicates using the qPCR BiomarkTM HD system (Fluidigm) based on 96.96 dynamic arrays (GE chips), as previously described in [39]. In brief, a pre-amplification step was performed with a $500 \mathrm{nM}$ pool of all primers in TaqMan-PreAmp Master Mix (Applied Biosystems) and $1.3 \mu \mathrm{l}$ cDNA per sample at 10 
min at $95^{\circ} \mathrm{C} ; 14$ cycles: $15 \mathrm{~s}$ at $95^{\circ} \mathrm{C}$ and $4 \mathrm{~min}$ at $60^{\circ} \mathrm{C}$. Obtained PCR products were diluted 1:10 with low EDTA-TE buffer. The pre-amplified product was loaded onto the chip with SsoFastEvaGreen Supermix Low Rox (Bio Rad) and DNA-Binding Dye Sample Loading Reagent (Fluidigm). Primers were loaded onto the chip at a concentration of $50 \mu \mathrm{M}$ in Assay Loading Reagent (Fluidigm) and low EDTA-TE Buffer. The chip was run according to the Fluidigm 96.96 PCR protocol with a Tm of $60^{\circ} \mathrm{C}$. qBase+ software verified stability of housekeeping gene expression throughout analysed samples $(\mathrm{M}<0.4$; according to [40]). Gene expression was normalised $(\Delta \mathrm{Ct})$ to the geometric mean of the two most stable housekeeping genes ( $r p s 18$, ef 1$)$. Further analysis of gene expression was carried out according to the $2^{-\Delta \Delta \mathrm{Ct}}$ method, in relation to the $16^{\circ} \mathrm{C}$ sample of Day 0 from female 1 [33]. This calculation allowed us to test for effects induced by temperature and larval age at specific developmental stages and in real time.

Table 1: Oligos used for molecular analysis of immune-related gene expression in Anguilla anguilla.

\begin{tabular}{|c|c|c|c|c|c|}
\hline Function & Gene name & $\begin{array}{l}\text { Abbre- } \\
\text { viation }\end{array}$ & $\begin{array}{l}\text { Prim } \\
(\mathrm{FW}\end{array}$ & $\begin{array}{l}\text { sequence } \\
\text { Forward, RV: Reverse) }\end{array}$ & Accession \\
\hline \multirow{6}{*}{ Housekeeping } & \multirow{2}{*}{$\begin{array}{l}18 \mathrm{~S} \text { ribosomal } \\
\text { RNA }\end{array}$} & \multirow{2}{*}{ RSP18 } & FW & AGAGCAGGGGAACTGACTGA & \multirow{2}{*}{ AZBK01681648 } \\
\hline & & & RV & ACCTGGCTGTATTTGCCATC & \\
\hline & \multirow{2}{*}{ Tubulin $\beta$} & \multirow{2}{*}{ Tubb } & FW & TGATGAGCACGGTATTGACC & \multirow{2}{*}{ AZBK01756733.1 } \\
\hline & & & RV & TGGCACATACTTTCCACCAG & \\
\hline & \multirow{2}{*}{$\begin{array}{l}\text { Elongation } \\
\text { Factor } 1\end{array}$} & \multirow{2}{*}{ EF1 } & FW & CTGAAGCCTGGTATGGTGGT & \multirow{2}{*}{ EU407824.1 } \\
\hline & & & RV & CATGGTGCATTTCCACAGAC & \\
\hline \multirow{4}{*}{$\begin{array}{l}\text { Complement } \\
\text { system }\end{array}$} & \multirow{2}{*}{$\begin{array}{l}\text { Complement } \\
\text { component C3 }\end{array}$} & \multirow{2}{*}{$\mathrm{C} 3$} & FW & AATATGTGCTCCCAGCCTTC & \multirow{2}{*}{ GBXM01025382.1 } \\
\hline & & & $\mathrm{RV}$ & GATAACTTGCCGTGATGTCG & \\
\hline & \multirow{2}{*}{$\begin{array}{l}\text { Complement } \\
\text { Component 1, Q } \\
\text { Subcomponent, } \\
\text { C Chain }\end{array}$} & \multirow[b]{2}{*}{$\mathrm{C} 1 \mathrm{qc}$} & FW & ACAATGTCGACACAGGCAAG & \multirow[b]{2}{*}{ GBXM01013997.1 } \\
\hline & & & RV & ACTTGGTTGAGGTTGGAGGTC & \\
\hline \multirow{4}{*}{$\begin{array}{c}\text { Pro- } \\
\text { inflammatory } \\
\text { Cytokines }\end{array}$} & \multirow{2}{*}{$\begin{array}{l}\text { Tumor necrosis } \\
\text { factor } \alpha\end{array}$} & \multirow{2}{*}{$\mathrm{TNFa}$} & FW & TCTGCGATGCTATTCCACTG & \multirow{2}{*}{ JQ793636.1 } \\
\hline & & & RV & TTCAAGTTCTGCTGGTGCTC & \\
\hline & \multirow{2}{*}{ Interleukin $1 \beta$} & \multirow{2}{*}{ IL1 $\beta$} & FW & ATTGGCTGGACTTGTGTTCC & \multirow{2}{*}{ AZBK01652159.1 } \\
\hline & & & $\mathrm{RV}$ & CATGTGCATTAAAGCTGACCTG & \\
\hline \multirow{3}{*}{$\begin{array}{c}\text { Anti- } \\
\text { inflammatory } \\
\text { cytokine }\end{array}$} & \multirow[b]{2}{*}{ Interleukin 10} & \multirow{2}{*}{ IL10 } & FW & CCTGCAAGAAACCCTTTGAG & \multirow{2}{*}{ AZBK01749637.1 } \\
\hline & & & $\mathrm{RV}$ & TGAACCAGGTGTCAATGCTC & \\
\hline & Interferon & \multirow{2}{*}{ IRF7 } & FW & TTCCTTGGAAGCACAACTCC & \multirow{2}{*}{ KF577784.1 } \\
\hline \multirow{3}{*}{$\begin{array}{l}\text { Induce type I } \\
\text { Interferon (ant- } \\
\text { viral) }\end{array}$} & $\begin{array}{l}\text { Regulatory } \\
\text { Factor } 7\end{array}$ & & $\mathrm{RV}$ & TGTCGTTCGGATTCTCTCTG & \\
\hline & \multirow{2}{*}{$\begin{array}{l}\text { Interferon } \\
\text { Regulatory } \\
\text { Factor } 3\end{array}$} & \multirow{2}{*}{ IRF3 } & FW & GAAGAGGTGGCAGCAAAATC & \multirow{2}{*}{ KF577783.1 } \\
\hline & & & RV & GGAAAAAGAGGGGGATTCAC & \\
\hline
\end{tabular}




\begin{tabular}{|c|c|c|c|c|c|}
\hline \multirow{2}{*}{$\begin{array}{c}\text { Antibacterial } \\
\text { response }\end{array}$} & \multirow{2}{*}{$\begin{array}{l}\text { Lysozyme Type } \\
\text { C }\end{array}$} & \multirow{2}{*}{ LysC } & & & \multirow{2}{*}{ AZBK01554584 } \\
\hline & & & RV & TGGAGCACGGGATATTACAG & \\
\hline \multirow{2}{*}{$\begin{array}{l}\text { Pathogen } \\
\text { recognition }\end{array}$} & \multirow{2}{*}{$\begin{array}{l}\text { Toll like } \\
\text { receptor } 2\end{array}$} & \multirow{2}{*}{ TLR2 } & FW & TGGTTCTGGCTGTAATGGTG & \multirow{2}{*}{ AZBK01853964.1 } \\
\hline & & & RV & CGAAATGAAGGCATGGTAGG & \\
\hline \multirow{2}{*}{$\begin{array}{c}\text { Antigen } \\
\text { presentation to } \\
\text { immune cells }\end{array}$} & \multirow{2}{*}{$\begin{array}{l}\text { Major } \\
\text { histocompatibili } \\
\text { ty complex, } \\
\text { Class II }\end{array}$} & \multirow[b]{2}{*}{ MHC 2} & FW & TCAAATTGACCTGGCTGAGAG & \multirow[b]{2}{*}{ AF134926.1 } \\
\hline & & & RV & TTTCCATTAGCCAGCTCCTC & \\
\hline \multirow{2}{*}{ Antibody } & \multirow{2}{*}{$\begin{array}{l}\text { Immunoglobulin } \\
\text { M }\end{array}$} & \multirow{2}{*}{$\operatorname{IgM}$} & $\mathrm{F}$ & CCAAGGACCATTCTTTCGTC & \multirow{2}{*}{ EU551246.1 } \\
\hline & & & RV & ACTGGCTTTCAGGAAGATGC & \\
\hline \multirow{2}{*}{$\begin{array}{l}\text { T-cell co- } \\
\text { receptor }\end{array}$} & \multirow{2}{*}{$\begin{array}{l}\text { Cluster of } \\
\text { differentiation } 3\end{array}$} & \multirow{2}{*}{ CD3 } & FW & AACCGATGATGCTGGAGAAG & \multirow{2}{*}{ AZBK01640579.1 } \\
\hline & & & $\mathrm{RV}$ & ATGTGTATTCGCCCGAACTG & \\
\hline
\end{tabular}

\subsection{Statistical analysis}

Tissue specific expression was tested using one-way ANOVAs with parental cross stated as random term. The difference between control samples and samples infected with AngHV-1 was statistically analysed using Mann-Whitney tests for each gene. Statistical models were used to investigate temperature effects on larval morphology and gene expression throughout early larval development (0 to $18 \mathrm{dph}$ ) and at specific developmental stages (Stages 1-3). Across the temperature treatments, Stage 1 represents the day of hatch, Stage 2 represents the timing of teeth formation, and Stage 3 represents the first-feeding stages [12]. Together, this allowed us to decipher changes in temperature in real-time and at standardized developmental intervals.

To examine the effect of temperature on gene expression throughout early development, we used two statistical approaches. In the first approach, we analysed the data using a series of repeated measures mixed-model ANOVAs (PROC MIXED; SAS Institute 2003). Models contained the temperature $\left(16,18,20\right.$ and $\left.22^{\circ} \mathrm{C}\right)$ and age $(0$ to $18 \mathrm{DPH})$ or stage $(1,2$ and 3$)$ main effects as well as the temperature $\times$ age (or stage) interaction term. Akaike's (AIC) and Bayesian (BIC) information criteria were used to assess which covariance structure (compound symmetry, autoregressive order, or unstructured) was most appropriate [41]. Temperature and age (or stage) were considered fixed, whereas parental cross was considered random. Tukey's post-hoc analyses were used to compare means between treatments. If a significant temperature $\times$ age (or stage) interaction was detected, the model was decomposed into a series of reduced one-way ANOVA models to determine the effect of temperature for each age (or stage) and of age (or stage) for each temperature. This was the case for $i l 1 \beta, \operatorname{lys} c, i r f 7$, and $m h c 2$. Reduced one-way ANOVA models 
involved only pre-planned comparisons and did not include repeated use of the same data, so alpha level corrections for a posteriori comparison were not necessary.

In the second approach, we examined variation in gene expression, throughout development at each temperature, by fitting linear, quadratic, or cubic equations (PROC REG; SAS Institute 2003). This allowed us to create predictive models to explore patterns of variation throughout early development at each temperature. Linear, quadratic, or cubic equations were chosen a-priori to fit the data [42]. Final equation selection (linear, quadratic, or cubic) was based on an F-statistic: d.f.j $\times$ $\left(R^{2} j-R^{2} i\right) /\left(1-R^{2} j\right)$, where: $R^{2} i=$ the $R^{2}$ for the $i$-th order, $R^{2} j=$ the $r^{2}$ for the next higher order, d.f. $f=$ the degrees of freedom for the higher-order equation with $\mathrm{j}$ degrees of freedom in the numerator and d.f.j $=\mathrm{n}-\mathrm{j}-1$ degrees of freedom in the denominator [42]. Graphs and regressions were prepared in SigmaPlot ${ }^{\circledR}$ (Version 13.0).

\section{Results:}

\subsection{Characterisation of tissue specific gene expression:}

Target genes were characterised for their expression in various tissues of on-grown farmed European eels (Fig. 1). Only baseline levels of irf3 expression could be detected in all studied organs (Fig. 1B). On the contrary, interferon regulator factor 7 (irf7) demonstrated low expression in brain, heart, muscle as well as head kidney but significantly higher mRNA levels $(\mathrm{P} \leq 0.05$; Fig. 1C) were detected in the hind-gut (145 \pm 26 -fold compared to head-kidney). Tissue specific expression also varied amongst cytokines: mRNA levels of interleukin (ill $\beta)$ were highest in gills (2844 \pm 1517 -fold) and skin (1450 \pm 953 -fold) (both $\mathrm{P} \leq 0.05$ compared to brain; Fig. 1D), followed by the immune organs. Variation between individuals was high and no significant differences between organs were detected for the expression of tumor necrosis factor $\alpha(\operatorname{tnf} \alpha)$ (Fig. 1E). However, illo was mainly expressed in head kidney $(606 \pm 326$-fold compared to heart with $\mathrm{P} \leq$ 0.05; Fig. 1F). In regard to the adaptive immune system, immunoglobulin $\mathrm{M}$ (igm) seemed to be expressed in the hind-gut, gills, and head kidney, with the highest expression in kidney $(91 \pm 26$ fold compared to the liver with $\mathrm{P} \leq 0.01$; Fig. $1 \mathrm{G}$ ). High intra-individual variability was observed for $c d 3$ and $m h c 2$, which led to no significant differences between tissues to be detected (Fig. H, I). Differential tissue expression was detected for the two complement components analysed: whilst $c 3$ was mainly expressed in liver ( $\mathrm{P} \leq 0.05$ compared to all other organs; Fig. 1J), clqc was least expressed in this organ but highest in the head kidney and kidney ( $\mathrm{P} \leq 0.05$; Fig. K). The expression 
of the toll like receptor $2(t \operatorname{lr} 2)$ was $160 \pm 52$-fold higher in the hind-gut than in the other investigated organs $(\mathrm{P} \leq 0.05$; Fig. 1L). 

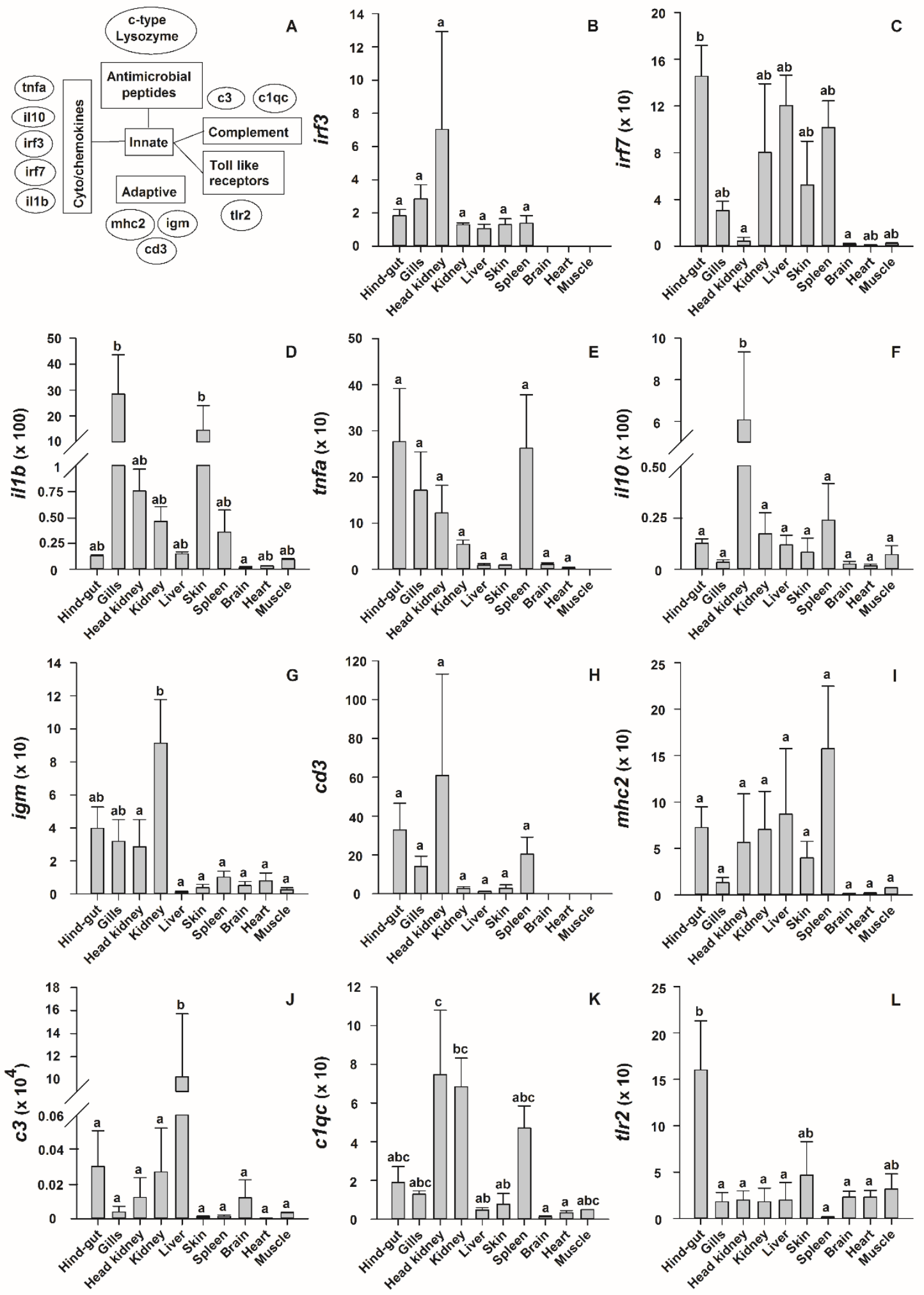

Fig. 1: Tissue specific expression of immune-related genes in on-grown farmed female $\boldsymbol{A}$.

anguilla. A) Overview of genes targeted in the present study. B-L) Expression of immune-related 
genes in certain tissues of European eel. Data are presented as mean \pm SEM $(n=3)$. Gene expression is displayed as $\mathrm{x}$-fold expression compared to the organ with lowest mRNA levels. Values with the same letters are not significantly different $(\mathrm{P}>0.05)$.

\subsection{AngHV-1 infection}

At the point of sampling no clinical signs of AngHV-1 were visible. Infection of tail tissue with AngHV-1 increased the expression of two of the characterised genes (Fig. 2). An increase in expression was observed for the innate immune factor $i l 1 \beta$, which was up-regulated approximately 3 -fold (dct $i l 1 \beta$ control $6.70 \pm 0.17$, infection $5.29 \pm 0.45$ ). Interestingly, the strongest response was observed for $m h c 2$, which displayed a $6.13 \pm 1.65$-fold increase in expression due to AngHV-1 (dct $3.25 \pm 0.34$ ) compared to the uninfected control treatment (det $5.68 \pm 0.86$ ).

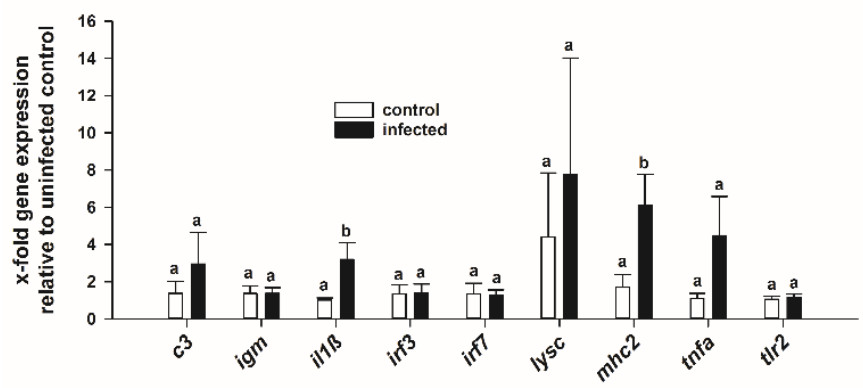

Fig. 2: Expression of immune-related genes in response to AngHV-1 infection.

Tail tissue explants of European eel were infected with 5 x $10^{5}$ TCID $_{50}$ of AngHV-1 in vitro for 36 hours. Values represent means $( \pm$ SEM) of five biological replicates. Treatments with the same letters are not significantly different $(\mathrm{P}>0.05)$.

\subsection{Development of the larval immune system:}

Generally, increasing temperature accelerated development, resulting in larvae reaching the first-feeding stage in 8 days at $22^{\circ} \mathrm{C}, 10$ days at $20^{\circ} \mathrm{C}, 12$ days at $18^{\circ} \mathrm{C}$, and 16 days at $16^{\circ} \mathrm{C}$. Housekeeping $(\mathrm{HK})$ gene expression was stable $(\mathrm{M}<0.4)$ throughout the experiment (see Fig. S1, supplement) and variance in HK expression was clearly coupled to variation in cDNA amount in samples. No mRNA of complement component $c l q c$ and T-cell marker $c d 3$ was detected in the studied larvae. Gene expression of the cytokine $\operatorname{tnf} \alpha$ was low (ct > 26) and not affected by temperature nor larval age and no temperature $\times$ age interaction was detected. For details on the observed regression please refer to Table $\mathrm{S} 1$ in the supplementary material. If not otherwise 
indicated, $\mathrm{x}$-fold values and $\Delta \mathrm{ct}$-values are given as mean \pm SEM of all temperatures combined (indicated as $\Delta \mathrm{ct}(\overline{\mathrm{T}})$ ).

Complement component $\mathrm{c} 3$ is the central molecule in the activation pathway of complement and thus its protein levels are linked to complement activity. During development, it was observed that larval gene expression was related to age or stage ( $<<0.0001$; Fig. 3A, D), such that gene expression of $c 3$ significantly decreased with increasing age from $0.77 \pm 0.06$-fold $(\Delta \operatorname{ct}(\overline{\mathrm{T}}): 4.18 \pm$ $0.20)$ on 0 dph to a minimum of $0.13 \pm 0.06$-fold $(\Delta \operatorname{ct}(\overline{\mathrm{T}}) 6.61 \pm 0.20)$ on day 12 ph (Fig. 3D). Immunoglobulin $\mathrm{M}$ is the first antibody to respond to an infection and has been dubbed a natural antibody in both mammals and teleosts as it can respond to pathogens without prior immunisation [43]. Thus, providing initial protection before the adaptive immune response is formed. Its mRNA levels decreased significantly with increasing stage $(\mathrm{P}<0.0001$; Fig. $3 \mathrm{I})$ and age $(\mathrm{P}<0.0001$; Fig. 3L) displaying a maximum expression $(2.16 \pm 0.30$-fold, $\Delta \operatorname{ct}(\overline{\mathrm{T}}): 9.42 \pm 0.21)$ on day 0 and a constant expression level of $0.48 \pm 0.03$-fold $(\Delta \operatorname{ct}(\overline{\mathrm{T}}): 11.51 \pm 0.10)$ after that.

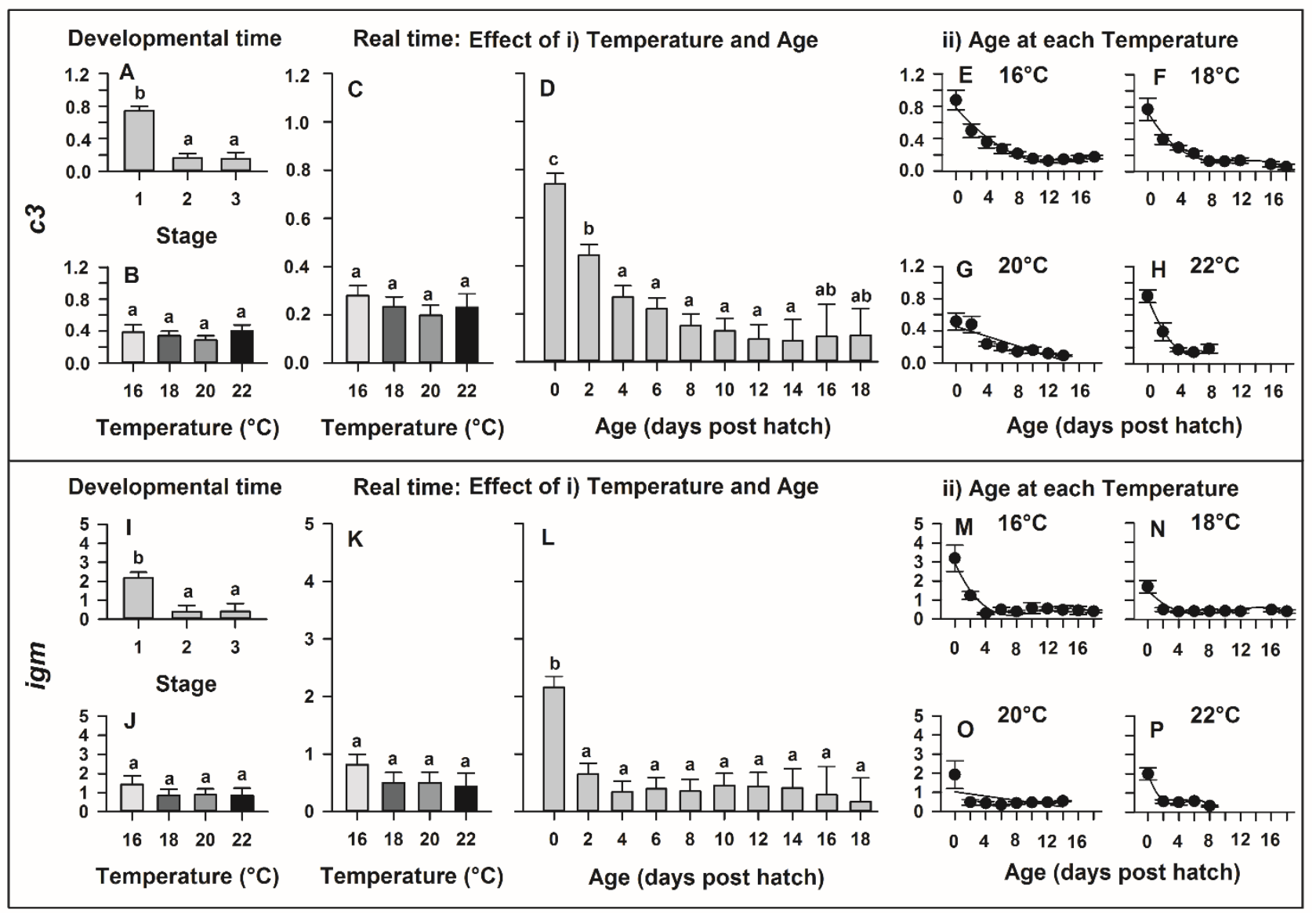

Fig. 3: Gene expression of $c 3$ and igm in European eel (Anguilla anguilla) larvae reared under four different temperatures. All y-axes display $\mathrm{x}$-fold expression in relation to the $16^{\circ} \mathrm{C}$ sample of day 0 from female 1 . The expression at specific developmental stages (1: hatching, 2: teeth 
formation, 3: first-feeding) is displayed for $c 3$ (A-B) and igm (I-J) whilst expression measured in real time is displayed in C-D for $c 3$ and K-L for igm. E-H and M-P show the effect of age on $c 3$ and igm, respectively. Relationships between age and $c 3$ expression can be explained by a cubic regression at $18^{\circ} \mathrm{C}$, a linear regression at $20^{\circ} \mathrm{C}$ and quadratic regressions at 16 or $22^{\circ} \mathrm{C}\left(\mathrm{P}<0.01 ; \mathrm{R}^{2}\right.$ $>0.78$ ). Relationships between age and igm expression can be explained by a linear regression at $20^{\circ} \mathrm{C}$ and cubic regressions at 16,18 or $22^{\circ} \mathrm{C}\left(\mathrm{P}<0.001 ; \mathrm{R}^{2}>0.16\right)$. Values represent means $( \pm$ SEM $)$ among four crosses at each temperature and treatments with the same letters are not significantly different $(\mathrm{P}>0.05)$.

Moreover, mRNA levels of major histocompatibility complex II ( $m h c 2)$ were also significantly affected by stage as transcription increased beyond stage 2 (teeth formation; $\mathrm{P}=0.001$; Fig. 4A). MHC II is located on the cell surface of antigen-presenting cells (e.g. macrophages, Bcells) and it fulfils the function of presenting extracellular antigens to immune cells. The expression of $m h c 2$ increased more than 2 -fold at 16 and at $22^{\circ} \mathrm{C}(\mathrm{P}=0.003)$ compared to the other temperatures, though no significant temperature $\times$ stage interaction was detected (Fig. 4B). On the contrary, when analysed in real time, a significant temperature $\times$ age interaction $(P=0.043)$ was observed, which allowed us to determine the effects of temperature for each age (Fig. 4C) and of age for each temperature (Fig. 4D-G). Here, $22^{\circ} \mathrm{C}$ showed the largest effect as it led to an increase of $m h c 2$ levels of $13.71 \pm 3.76$-fold at $4 \mathrm{dph}, 13.27 \pm 0.93$ at $6 \mathrm{dph}$, and $39.60 \pm 6.54$ at $8 \mathrm{dph}$ (all P $\leq 0.01$ ). Furthermore, larval age significantly influenced expression of $m h c 2$ (Fig. 4D-F) when larvae were reared at temperatures ranging from 16 to $20^{\circ} \mathrm{C}(\mathrm{P} \leq 0.01)$, while no age effect was observed at $22^{\circ} \mathrm{C}$ (Fig. 4G). This leads to a steady increase in mRNA levels throughout development of the larvae. Initial detection of antigens is amongst others carried out by toll like receptors. In fish, toll like receptor 2 (TLR2) is involved in the recognition of bacterial and parasitic ligands [44]. As shown in Fig. 4H, expression of $t$ tr2 approximately doubled at stage 2 (teeth formation) and tripled at stage 3 (first-feeding; $\mathrm{P}<0.0001$ ). It was also significantly affected in real time $(\mathrm{P}<0.0001)$ and increased with increasing age from a minimum expression of $0.62 \pm 0.09$ fold ( $\Delta$ ct: $10.52 \pm 0.15)$ on $2 \mathrm{dph}$ to a maximum expression of $4.34 \pm 0.23$-fold $(\Delta \mathrm{ct}: 7.48 \pm 0.08)$ on 16 dph (Fig. 4K). 


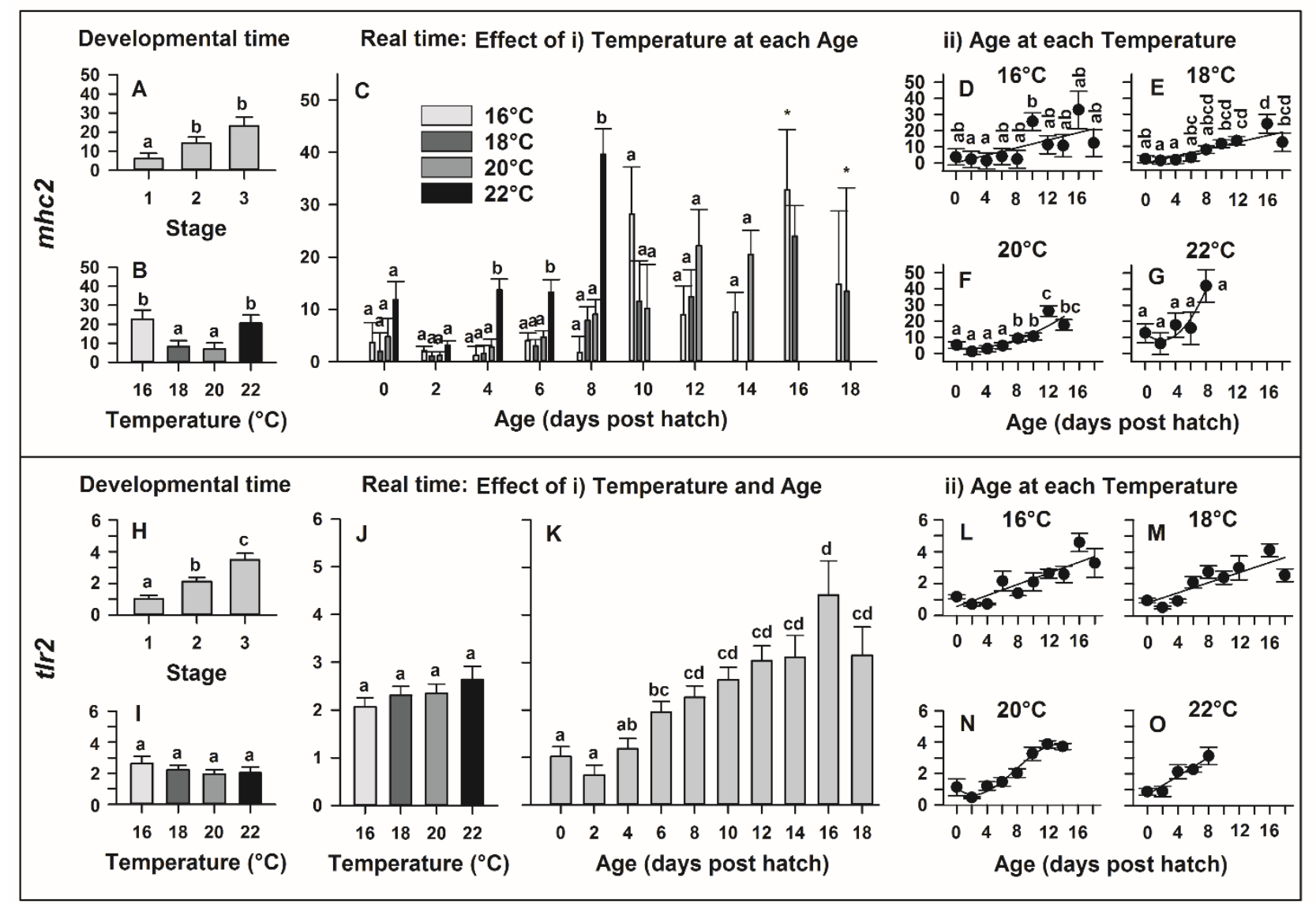

Fig. 4: Gene expression of $m h c 2$ and $t$ tr2 in European eel (Anguilla anguilla) larvae reared under four different temperatures. All $\mathrm{y}$-axes display $\mathrm{x}$-fold expression in relation to the $16^{\circ} \mathrm{C}$ sample of day 0 from female 1 . The expression at specific developmental stages (1: hatching, 2 : teeth formation, 3: first-feeding) is displayed for $m h c 2$ (A-B) and $t l r 2$ (H-I), whilst expression measured in real time is displayed in $\mathrm{C}$ for $m h c 2$ and $\mathrm{J}-\mathrm{K}$ for $t l r 2$. D-G and L-O show the effect of age on $m h c 2$ and $t l r 2$, respectively. Relationships between age and $m h c 2$ expression can be explained by linear regressions at 16 or $18^{\circ} \mathrm{C}$ and quadratic regressions at 20 or $22^{\circ} \mathrm{C}(\mathrm{P}<0.0001$; $\mathrm{R}^{2}>0.36$ ). The relationship between age and $t l r 2$ expression can be explained by a cubic regression at $20^{\circ} \mathrm{C}$ and linear regressions at 16,18 or $22^{\circ} \mathrm{C}\left(\mathrm{P}<0.002 ; \mathrm{R}^{2}>0.66\right)$. Data points with an asterisk (*) were not included in the statistical model due to insufficient sample size. Values represent means $( \pm \mathrm{SEM})$ among four crosses at each temperature and treatments with the same letters are not significantly different $(\mathrm{P}>0.05)$.

Type I IFNs are cytokines, which are expressed in response to the detection of viral antigens and elicit an antiviral immune response. The expression of type I IFNs is regulated with the Interferon regulating factors 3 and 7 (irf3 and 7) and in the present study, we demonstrate that their 
expression is dependent on larval stage (Fig. 5A, B, I, J; P < 0.0001), and age (Fig. 5D, K; P < 0.0001 ) as well as temperature when measured in real time (Fig. 5C, K; P < 0.029). Gene expression of $\operatorname{irf3}$ was significantly elevated $(6.66 \pm 0.69$-fold $)$ at $22^{\circ} \mathrm{C}$ compared to $(4.59 \pm 0.45$ fold) $16^{\circ} \mathrm{C}$ (Fig. 5C) and significantly increased throughout ontogeny with increasing larval age (Fig. 5D). Here, general expression was $2.24 \pm 0.25$-fold $(\Delta \operatorname{ct}(\overline{\mathrm{T}}): 11.29 \pm 0.16)$ on day 0 and increased in a linear manner to reach a maximum of $8.26 \pm 0.78$-fold $(\Delta \operatorname{ct}(\overline{\mathrm{T}}): 9.19 \pm 0.14)$ at 14 dph. Irf7 was significantly affected by the temperature $\times$ age interaction $(\mathrm{P}=0.013)$. Significant differences in mRNA levels of irf7 among temperatures occurred on $4 \mathrm{dph}(\mathrm{P}=0.045)$ where expression at $22^{\circ} \mathrm{C}$ was about $40 \%$ higher than the expression at $16^{\circ} \mathrm{C}$ (Fig. $5 \mathrm{~K}$ ). Additionally, irf7 levels increased steadily throughout development in all tested temperatures $\left(16-22^{\circ} \mathrm{C} ; \mathrm{P} \leq 0.007\right.$; Fig. 5L-O).

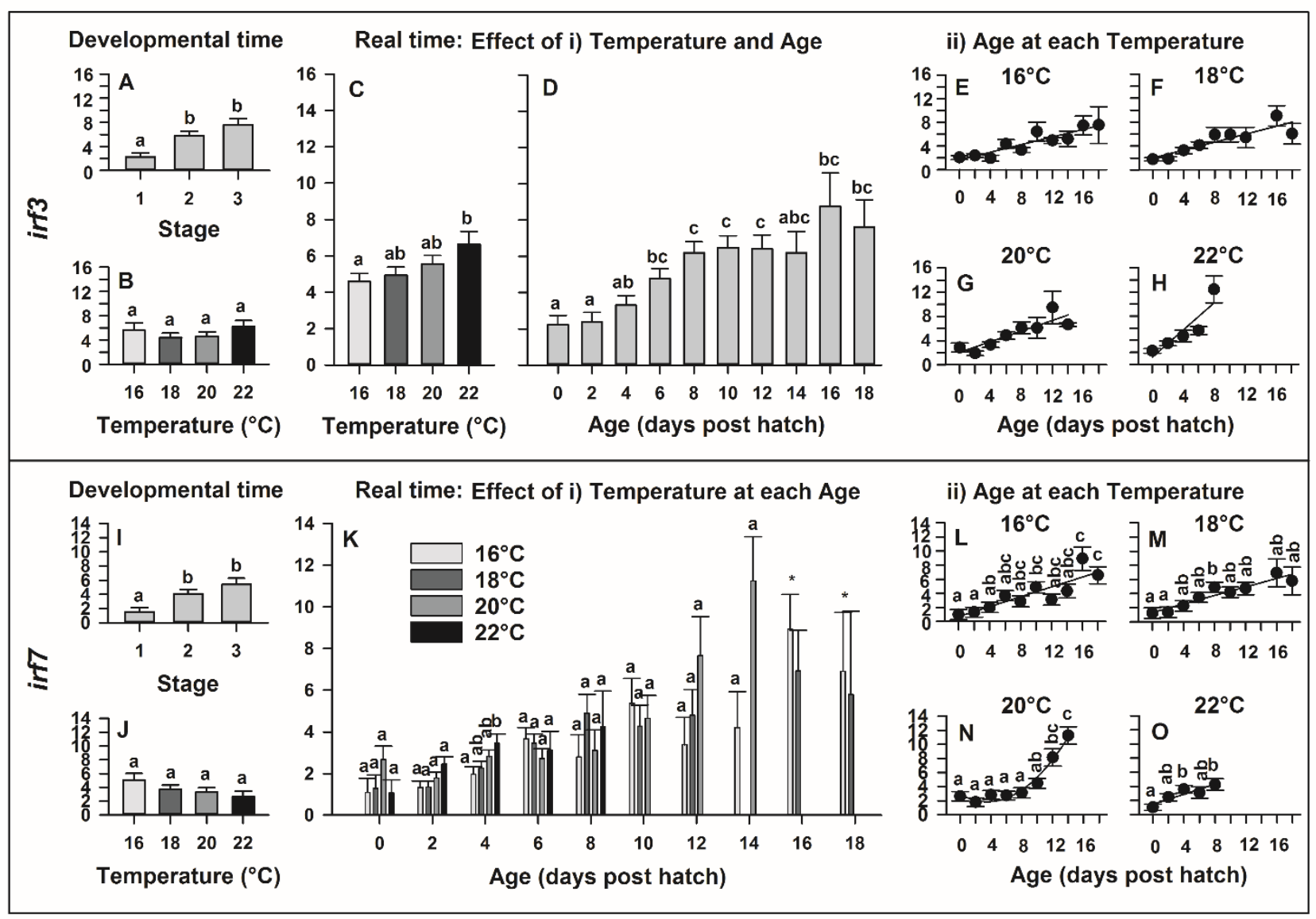

Fig. 5: Gene expression of irf3 and irf7 in European eel (Anguilla anguilla) larvae reared under four different temperatures. All y-axes display $\mathrm{x}$-fold expression in relation to the $16^{\circ} \mathrm{C}$ sample of day 0 from female 1 . The expression at specific developmental stages (1: hatching, 2 : teeth formation, 3: first-feeding) is displayed for $\operatorname{irf} 3$ (A-B) and $\operatorname{irf7}(\mathrm{I}-\mathrm{J})$, whilst expression measured in real time is displayed in C-D for irf and K-L for irf7. E-H and M-P show the effect of 
age on $\operatorname{irf} 3$ and $\operatorname{irf} 7$, respectively. Relationships between age and $\operatorname{irf} 3$ expression can be explained by linear regressions at all temperature treatments $\left(\mathrm{P}<0.0001 ; \mathrm{R}^{2}>0.74\right)$. The relationship between age and irf7 expression can be explained by a quadratic regression at $20^{\circ} \mathrm{C}$ and linear regressions at 16,18 or $22^{\circ} \mathrm{C}\left(\mathrm{P}<0.002 ; \mathrm{R}^{2}>0.72\right)$. Data points with an asterisk (*) were not included in the statistical model due to insufficient sample size. Values represent means ( \pm SEM) among four crosses at each temperature and treatments with the same letters are not significantly different $(\mathrm{P}>0.05)$.

Gene expression of the pro-inflammatory cytokine Interleukin $1 \beta(i l 1 \beta)$ was only significantly increased at stage 3 (first-feeding; $\mathrm{P}=0.033$ ) but at this stage it was up-regulated approximately 3fold (Fig. 6A). The real time analysis, however, revealed a significant temperature $\times$ age interaction (Fig. 6C; $\mathrm{P}=0.003$ ). Significant differences in gene expression of $i l 1 \beta$ among temperatures occurred on 6,8 and $12 \mathrm{dph}(\mathrm{P}<0.02)$. On $8 \mathrm{dph}$ in specific, expression levels of $i l 1 \beta$ were approximately 6-fold $(\Delta \mathrm{ct}: 5.96 \pm 0.97)$ higher at $22^{\circ} \mathrm{C}$ compared to the other temperatures $(\Delta \mathrm{ct}$ : $8.70 \pm 0.15)$. Larval age led to a significant increase in $i l 1 \beta$ expression at all rearing temperatures $(\mathrm{P}$ $\leq 0.001$ ) except at $20^{\circ} \mathrm{C}$ (Fig. 6D-G), probably due to high levels of variation between individuals at this temperature. A linear increase of $i l 1 \beta$ expression was observed at $16^{\circ} \mathrm{C}$ and $18^{\circ} \mathrm{C}(\mathrm{P}<0.0001$; $\mathrm{R}^{2} \geq 0.53$ ), leading to an approximately 4-fold increase within the sampling period. The relationships between age and $i l 1 \beta$ expression can be explained by a sigmoidal cubic regression at $22^{\circ} \mathrm{C}\left(\mathrm{P}<0.001 ; \mathrm{R}^{2}=0.95\right)$ with low levels of expression during the first $6 \mathrm{dph}$ and a sudden increase at $8 \mathrm{dph}$, resulting in the 6-fold up-regulation described above.

Expression of the antimicrobial c-type lysozyme (lysc) was also significantly up-regulated at the first-feeding stage (stage 3) by approx. 3-fold (Fig. 6H; $\mathrm{P}=0.0001$ ). Furthermore, expression of this gene was doubled at $22^{\circ} \mathrm{C}$ compared to $20^{\circ} \mathrm{C}$ (Fig. $6 \mathrm{I} ; \mathrm{P}=0.041$ ). In real time, the temperature $\times$ age interaction significantly influenced the gene expression of lysc (Fig. 6J; P $<0.0001)$. Here, significant differences in expression of lysc among temperatures occurred on 8, 12 and $14 \mathrm{dph}(\mathrm{P} \leq$ 0.04). More specifically, and in line with expression patterns of other genes at day $8 \mathrm{ph}$, a strong upregulation (300\%) of lysc at $22^{\circ} \mathrm{C}$ compared to the other temperatures was observed. Additionally, a rearing temperature of $16^{\circ} \mathrm{C}$ led to a significant lower level of expression of lysc compared to $18^{\circ} \mathrm{C}\left(16^{\circ} \mathrm{C}: \Delta \mathrm{ct}: 12.93 \pm 0.35,18^{\circ} \mathrm{C}: \Delta \mathrm{ct}: 11.37 \pm 0.45\right)$ on $12 \mathrm{dph}$ and compared to $20^{\circ} \mathrm{C}\left(16^{\circ} \mathrm{C}\right.$ : $\left.\Delta \mathrm{ct}: 13.11 \pm 0.92,20^{\circ} \mathrm{C}: \Delta \mathrm{ct}: 11.04 \pm 0.19\right)$ on $14 \mathrm{dph}$. Expression of lysc was also significantly affected by larval age (Fig. $6 \mathrm{~K}-\mathrm{N})$ at all rearing temperatures $(\mathrm{P} \leq 0.01)$. Similar to $i l 1 \beta$, expression 
of lysc linearly increased at $16^{\circ} \mathrm{C}\left(\mathrm{P}=0.012, \mathrm{R}^{2}=0.29\right)$ and $18^{\circ} \mathrm{C}\left(\mathrm{P}<0.001, \mathrm{R}^{2}=0.31\right)$ throughout larval development. The relationships between age and lysc expression can further be explained by a sigmoidal cubic regression at $20^{\circ} \mathrm{C}\left(\mathrm{P}<0.0001 ; \mathrm{R}^{2}=0.96\right)$ leading to a 9-fold expression at 14 dph $(\Delta \mathrm{ct}: 11.04 \pm 0.19)$ compared to day $0(\Delta \mathrm{ct:} 19.14 \pm 0.58$; Fig. $6 \mathrm{M})$. As observed in ill $\beta$, rearing larvae at $22^{\circ} \mathrm{C}$ led to a constant level of lysc expression during the first $6 \mathrm{dph}$ and a sharp increase in mRNA levels at $8 \mathrm{dph}$. This is best described by a parabolic quadratic regression at $22^{\circ} \mathrm{C}$ (Fig. $\left.6 \mathrm{~N} ; \mathrm{P}=0.0001 ; \mathrm{R}^{2}=0.59\right)$.

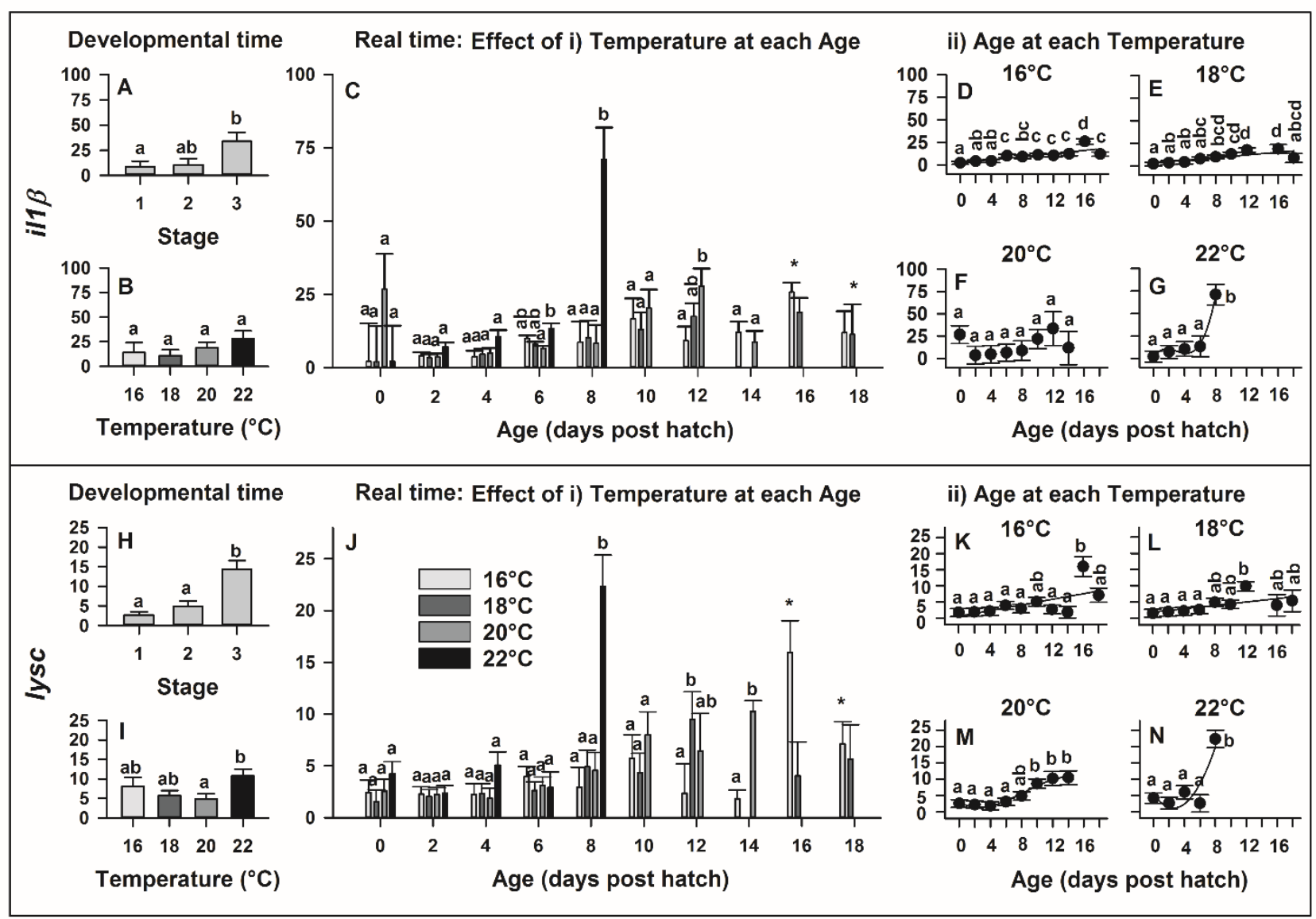

Fig. 6: Gene expression of illß and lysc in European eel (Anguilla anguilla) larvae reared under four different temperatures. All y-axes display $\mathrm{x}$-fold expression in relation to the $16^{\circ} \mathrm{C}$ sample of day 0 from female 1 . The expression at specific developmental stages (1: hatching, 2 : teeth formation, 3: first-feeding) is displayed for $i l 1 \beta$ (A-B) and lysc (H-I), whilst expression measured in real time is displayed in $\mathrm{C}$ for $i l 1 \beta$ and $\mathrm{J}$ for lysc. D-G and K-N show the effect of age on $i l 1 \beta$ and lysc, respectively. Relationships between age and $i l 1 \beta$ expression can be explained by linear regressions at 16 or $18^{\circ} \mathrm{C}$ and a cubic regression at $22^{\circ} \mathrm{C}\left(\mathrm{P}<0.0001 ; \mathrm{R}^{2}>0.53\right)$. The relationship between age and lysc expression can be explained by linear regressions at 16 or $18^{\circ} \mathrm{C}$, a cubic regression at $20^{\circ} \mathrm{C}$ and a quadratic regression at $22^{\circ} \mathrm{C}\left(\mathrm{P}<0.002 ; \mathrm{R}^{2}>0.29\right)$. Data points with 
an asterisk $(*)$ were not included in the statistical model due to insufficient sample size. Values represent means $( \pm$ SEM) among four crosses at each temperature and treatments with the same letters are not significantly different $(\mathrm{P}>0.05)$.

\section{Discussion:}

The ultimate aim of this study was to elucidate the expression patterns of key immune genes during $A$. anguilla development and investigate how temperature influences these patterns. As no molecular tools were available to analyse immune-related genes in this fish species, we first set out to develop primers and characterize tissue specific expression of immune-related genes in healthy on-grown farmed individuals. Subsequently, the usability of this tool was evaluated during AngHV1 exposure of tail explant cultures. Once their usability was established, we applied these new tools to study the 'critical' early life stages of eel across a broad thermal regime.

\subsection{Tissue specific expression \& AngHV-1 infection}

Complement activation leads to the production of activated protein fragments that play an important role in innate immune responses [26]. In mammals, and possibly in fish, C3 is the central complement molecule of the three pathways [26]. It is known that complement proteins are mainly synthesized in the liver in mammals and fish [45]. The tissue specific expression pattern for $c 3$ (highest expression in liver) in the present study is therefore in line with previous findings. Similar results have been observed in other fish species, such as yellow croaker (Larimichthys crocea), Indian major carp (Labeo rohita), and orange spotted grouper (Epinephelus coioides) [46-48]. The gene complement $\mathrm{C} 1 \mathrm{q} \mathrm{C}$ chain $(c l q c)$ encodes the large subunit $(\mathrm{C} 1 \mathrm{q})$ of the complement component $\mathrm{C} 1 . \mathrm{C} 1 \mathrm{q}$ acts as a pathogen sensor and binds directly to their surface or to antibodies bound to pathogens, which leads to the activation of the complement system via the classical pathway [28]. In mammals, C1q is mainly synthesized in macrophages and dendritic cells and not by hepatocytes unlike the other complement components [49]. This is reflected in the expression pattern observed in the analysed healthy eel tissue where $c l q c$ expression was very low in the liver but high in spleen, kidney, and head kidney. This pattern seems to be conserved across many fish species and orders as it was also observed in Siberian sturgeon (Acipenser baerii), mandarin fish (Siniperca chuatsi), and zebrafish (Danio rerio) [50-52]. Both investigated complement factors $c 3$ and $c l q c$ were not significantly up-regulated during AngHV-1, which is in line with results from common carp gills infected with cyprinid herpesvirus 3 (CyHV-3), which has been shown to be able 
to modulate the immune response of the host [53]. However, targeted studies are needed to investigate the immunuomodulatory potential of AngHV-1.

Toll-like receptors (TLR) were the first receptors identified that recognize pathogen associated molecular patterns (PAMPs) [54]. In European eel, TLR2 is suggested to recognize bacterial and fungal pathogens [30]. This is in line with our results where the expression was not regulated during AngHV-1 infection. The $t l r 2$ expression in the present study was especially low in the spleen but high in hind-gut. Throughout the literature, it is clear that tissue specific tlr2 expression varies among species [44,55-57]. As pathogens are often ingested with food or water, it was expected that tlr2 is highly expressed in the hind-gut. However, the lack of expression in the spleen was not expected as this is a major immune organ and future studies should address this phenomenon.

Cytokines include interleukins, tumor necrosis factors, interferons and chemokines. In this study, we investigated $i l 10, i l 1 \beta$ and $\operatorname{tnf} \alpha$ as well as the type 1 interferon inducing factors $\operatorname{irf} 3$ and irf7. In humans, IL-10 is mainly produced by monocytes [28], whilst in fish the functional role of IL-10 is still under investigation. It has been shown that, similar to the expression observed in eel, sea bass (Dicentrarchus labrax) and carp (Cyprinus carpio) produce this cytokine intensely in head kidney $[58,59]$. This indicates that the head kidney is a major side of monocytes in eel. IL- $1 \beta$ is produced by macrophages in response to signalling via toll-like receptors (TLRs) and induces an inflammatory immune response. For the eels used in this study, $i l l \beta$ was constitutively expressed in all studied organs with the highest expression in gills and skin. The latter is contrary to other fish species, such as brown trout (Salmo trutta) and rohu (Labeo rohita), where ill $\beta$ expression was always low in skin $[60,61]$. Interleukin- $1 \beta$ has been shown to be up-regulated in skin of fish following infection or injury as reviewed by [62]. Thus, it has to be investigated further if the high expression in skin is an eel specific characteristic or if it is due to an undetected infection or injury. Due to the low variability between the three tested individuals, this might be an eel specific trait attributed to their rudimentary scales and high mucus production [63]. Interestingly, ill $\beta$ was also one of the genes up-regulated during the AngHV-1 infection. This is in line with the response in carp to CyHV-3, which also induces pro-inflammatory responses in skin [64].

The main role of TNF- $\alpha$ is the control and local restriction of infection and the here observed tissue specific expression corresponds to a study in rainbow trout (Oncorhynchus mykiss) [65] but differs from expression patterns in other fish species, such as mandarin fish (Siniperca chuatsi), rohu, and crucian carp (Carassius carassius) [61,66-68]. This indicates, as previously discussed by Kajungiro and colleagues, that constitutive expression of $t$ f $f \alpha$ varies with fish species and tissues 
[67]. During exposure of the explants to AngHV-1 in our in vitro experiments, the up-regulation was noticed, however due to high variation it was not significant.

The interferon regulating factors 3 and 7 have been previously characterised in European eel [29]. In healthy organisms, IRF3 is constitutively expressed in a variety of tissues and is present in a latent inactive form in the cytoplasm [69]. On the other hand, IRF7 is expressed at low levels in the cytoplasm of lymphoid cells [70]. Both are strongly induced upon viral infection. Surprisingly, these two type I IFN response markers were not up-regulated during AngHV-1 infection, which should be further investigated in the future. However, the group of fish herpes viruses is known to have strong anti-interferon abilities [71]. The present study aimed, amongst others, to complement the knowledge from a previous A. anguilla study [29] by adding the tissue specific expression of these two genes. Irf3 was constitutively expressed at a low level in all analysed tissues whilst irf7 displayed higher expression levels in organs involved in the immune response except for head kidney. The latter not only concurs with the spatial pattern found in PolyI:C treated eels [29] but also resembles the pattern observed in crucian carp and Japanese flounder (Paralichthys olivaceus) $[72,73]$.

Immunoglobulin $\mathrm{M}(\operatorname{IgM})$ is, like all classes of immunoglobulins, produced by B-cells and therefore its expression gives an indication of the localisation of these immune cells. The observed tissue specific expression pattern of igm concurs with the pattern observed in turbot (Scophthalmus maximus) [74] whilst higher spleen expression levels were observed in pufferfish (Takifugu rubripes) [75]. The high expressions in head kidney and trunk kidney indicate the haematopoetic function of these organs in A. anguilla and confirm previous findings in New Zealand freshwater eels (A. australis schmidtii and A. dieffenbachii) [76]. The low expression of igm in spleen, similar to the expression of $t l r 2$ in this organ, is however unexpected and should be addressed in future studies. In respect to the AngHV-1 infection, igm up-regulation was not expected due to the early sampling point, which precedes activation of the adaptive immune response in teleosts [77].

Another member of the immunoglobulin superfamily is the clusters of differentiation (CD). In humans, CD3 is initially expressed in the cytoplasm of pro-thymocytes and migrates to the cell membrane when T-cells mature. Hence, CD3 is only expressed on T-cells and can therefore be used as a marker for the presence of this cell type. Our study showed that $c d 3$ was ubiquitously expressed in all tested immune organs of on-grown farmed European eel. Unfortunately, due to the involution of thymus in eels [76], it was not possible to test expression in thymus tissue. In fish, mature T-cells 
have been shown to be abundant in lymphoid tissues such as thymus, kidney, and spleen and in mucosal tissues (intestine and gills) [78].

The major histocompatibility complex (MHC) binds peptide fragments of pathogens and presents them on the cell surface for recognition by appropriate T-cells. In mammals, MHC II class molecules can be found on antigen-presenting cells, i.e. B-cells, macrophages, and dendritic cells [28]. A detailed characterization of MHC II in eel was beyond the scope of this study and thus we concentrated on the tissue specific expression. The $m h c 2$ expression pattern observed in the present analysis is similar to tissue expression recorded in swamp eel where hardly any expression was detected in heart and muscle, whilst the highest expression was observed in the stomach, spleen and skin [79]. Certain genotypes of MHC class II were shown to be associated with higher survival of carp to CyHV-3 [80]. Therefore, the up-regulation of $m h c 2$ gene could be considered important for the response to AngHV-1 as this might enable disease prevention methods for eel aquaculture in the future.

Taken together, our in vitro viral model infection induced pro-inflammatory responses marked with up-regulation of $i l 1 \beta$. Furthermore, up-regulation of $m h c 2$ links the responses with the adaptive arm of immunity. Interestingly, the antiviral responses markers ( $\operatorname{irf} 3$ and 7) were not upregulated which could be related with anti-IFN activities of alloherpesviruses. Considering the timepoint at which the samples were collected the findings fit to the initial phase of mucosa responses to the alloherpesviral pathogen [81].

As pointed out by [30], the phylogenetic distance to more common fish species and their status as non-model fish hampered the immune-related research of European eel in the past. However, advancement in the understanding of their immune system is vital to improve health and survival under rearing conditions [24]. The present study now provides new molecular tools to characterize the immune system of European eel in more depth and, as described below, to understand the development of the immune system and its response to environmental factors. We therefore applied these tools to elucidate expression of key immune genes during development of the immune system from hatch to the first-feeding stage. 


\subsection{Ontogeny at $18^{\circ} \mathrm{C}$}

Our findings showed that the studied immune genes could be clustered into three groups, which were differently affected by temperature: low-level age independent expression and expression positively or negatively correlated with age.

In a further analysis of the same larvae [34], $18-20^{\circ} \mathrm{C}$ was found to be the optimal temperature in regard to survival, growth, and development. In order to elucidate regular ontogeny of the immune system of European eel larvae, we therefore focused on the $18^{\circ} \mathrm{C}$ treatment to discuss temperature influences. Both complement component $c 3$ and immunoglobulin M (igm) seem to have been already expressed during the embryonic stage and might have been transferred maternally to the larvae as seen in various other fish species [45,82-85]. However, to confirm this, further studies are needed. It has previously been suggested that at this developmental stage, $c 3$ and igm work together to facilitate binding of opsonized bacteria to complement receptors on phagocytes [26,85]. In carp, it was demonstrated that $c 3$ gene expression peaked around the time of hatching and that it is produced in the yolk syncytial layer [45]. During eel ontogeny, $c 3$ gene expression was also linked to a shrinking yolk sac area [34], probably indicating that C3 is important for innate immune function shortly after hatch. Similar to $c 3$ and in line with the present study, it was shown in sea bass that IgM is transferred maternally through the yolk. Its persistence only lasted a few days and got exhausted with yolk absorption [86] to then completely disappear during later larval stages [87]. In the European eel larvae studied here, igm levels peaked at hatch and decreased rapidly to basal levels afterwards. Interestingly, studies on Japanese eel demonstrated that whilst igm and T-cell-related $l c k$ genes were expressed already 3 days post fertilisation, the development of lymphoid tissues were delayed and neither spleen, thymus nor lymphocytes were observed in larvae of similar sizes [25,88]. This is in line with the observed absence of $c d 3$ expression in the present study and it can therefore be assumed that adaptive immune protection is still underdeveloped in very early larval stages (i.e. pre-leptocephalus stage). Overall, this would have implications for the use of vaccines during early life stages, thus further studies are needed to link the present findings to the functionality of the adaptive immune system.

Toll like receptor 2 (TLR2) is involved in the recognition of bacterial and parasitic ligands. In this study, $t \operatorname{lr} 2$ expression increased throughout larval development in a temperature independent manner. To our knowledge, this is the first study investigating tlr2 expression during larval development of fish. However, it was previously shown that toll like receptors are already expressed before hatch and that their expression is temperature independent in zebrafish [89]. Our 
results therefore indicate that eel larvae were probably already able to detect pathogens and that this ability increased with age, which confirms that these receptors play an important part in immune surveillance throughout the different life stages [6]. Additionally, anti-bacterial protection is provided through the expression of lysozyme. This protein is one of the maternal immune factors that are transferred to the egg and it has been detected in the early life stages (oocytes to larvae) of various fish species $[90,91]$. For example, in brown trout lysc was constitutively expressed from the unfertilized egg to three weeks post hatch [60]. In the present study, mRNA of c-type lysozyme (lysc) were detected from day 0 onwards, and expression increased constantly during development resulting in the highest expression at the stage of first-feeding. This, together with the above described results on $t / r 2$ expression and the presence of skin lectin at $8 \mathrm{dph}$ in Japanese eel [25], indicates that innate antibacterial protection is an important factor in the immunological protection during early larval development in eel.

The cytokines TNF- $\alpha$ and IL1- $\beta$ induce a cell signalling cascade leading to an inflammatory immune response after detection of pathogen and danger associated molecular patterns (PAMPs, DAMPs) by respective receptors [28]. During eel ontogeny, expression of $i l 1 \beta$ increased steadily indicating an increase in the potential to mount a pro-inflammatory immune response and also the presence of cytokine producing immune cells, such as macrophages. Another indicator for the presence of these cells is the increasing expression of $m h c 2$ throughout eel larval development. On the contrary, tnfa was not expressed during the first $18 \mathrm{dph}$. This is very dissimilar to patterns observed in brown trout and rohu $[60,61]$. The effect an absence of tnfa would have on the innate immune response however needs to be established in further infection studies. Both interferon regulating receptors studied, exhibited a steady increase throughout larval development. This is similar to a study on zebrafish where irf 3 also increased during the course of larval development [20]. As IRFs regulate the transcription of interferons (IFNs), they are involved in the innate immune response to viruses. It can therefore be assumed that the potential of the eel larvae to mount an anti-viral immune response increases throughout development and is already present during the very early life stages.

A previous study [35] indicated a stratified survival curve in European eel larvae, i.e. low initial mortality, followed by a steep decline in survival until mortality subsides. Similar patterns have also been observed in various fish species such as turbot [39], winter flounder (Pseudopleuronectes americanus) [92], Pacific herring (Clupea pallasii) [93], and cod (Gadus 
morhua) [94] larvae. A period of unusually high mortality during fish larval development has previously been proposed under Hjort's critical period hypothesis and this critical period directly influences recruitment [95]. Previous studies link this period of high mortality to feeding success, size, predation, and life history strategy [95-97]. However, since such critical periods can also be observed in culture, it could, in addition, be linked to pathogen sensitivity, meaning that eel larvae are immunocompromised during early development. Our results indicate a sensitive phase (from $\sim 1$ dph to approximately the stage of teeth-formation) during which larvae most probably are immunocompromised and hence highly susceptible to pathogens (conceptualised in Fig. 7).
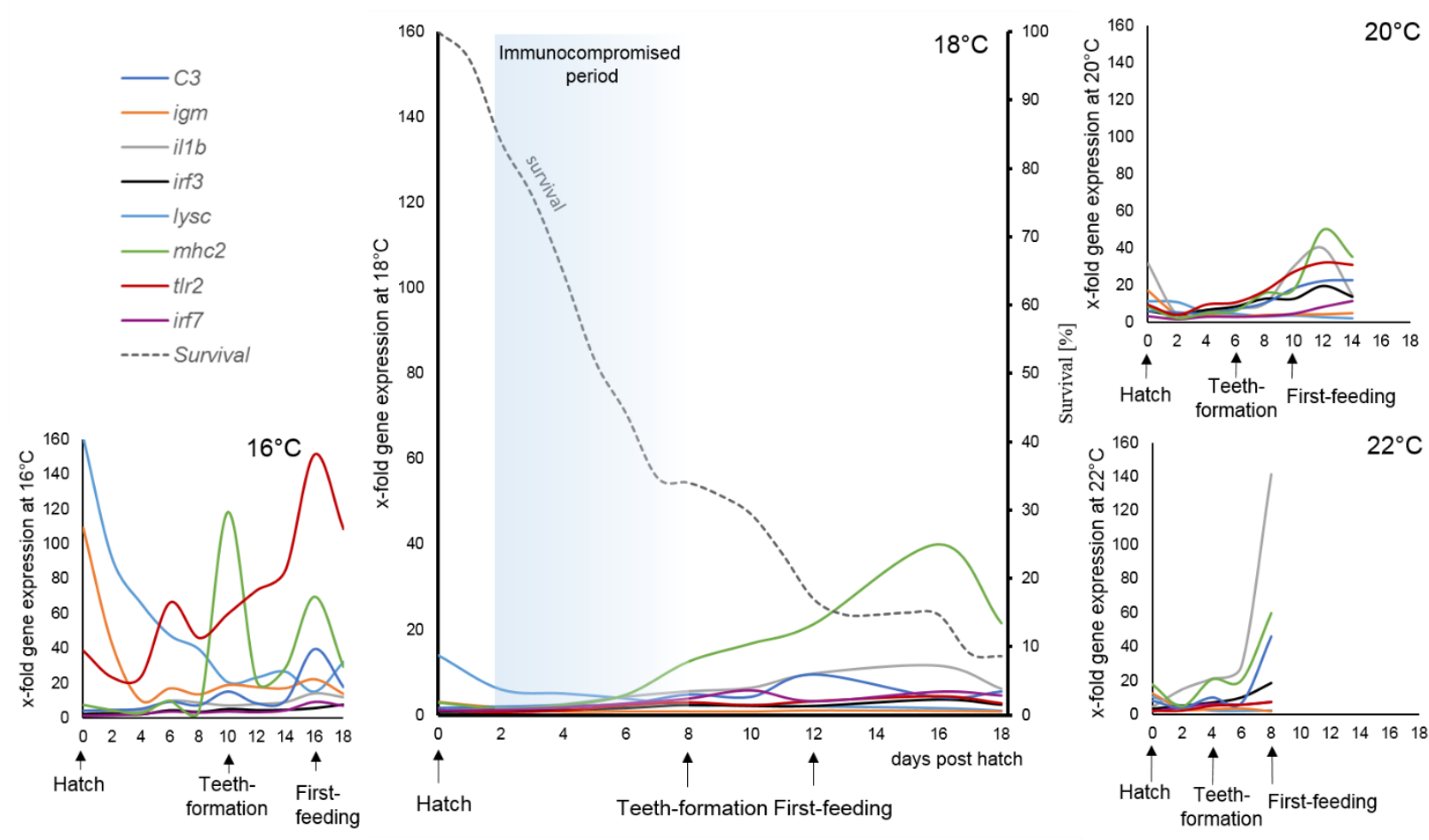

\section{Fig. 7: Conceptual overview - Immunocompromised window during development of}

European eel linked to survival. The left axis displays gene expression calculated for the respective rearing temperature only. Expression $\left(2^{-\Delta \Delta \mathrm{ct}}\right)$ was calculated in relation to the lowest mRNA level for each temperature. For parameter variation see Fig. 1-6. Survival (grey dashed line) is displayed on the right axis. For survival: Larvae from 12 parental combinations were stocked at $\sim 150$ larvae/L in a recirculation aquaculture system equipped with $\sim 45 \mathrm{~L}$ aquaria $(50 \times 30 \times 35 \mathrm{~cm})$, UV sterilizer, protein skimmer, and biofilter. Larvae were reared at $18^{\circ} \mathrm{C}$ in 36 ppt filtered (1-10 $\mu \mathrm{m})$ North Sea seawater supplemented with artificial salt. The number of surviving larvae was estimated per aquarium by subjective estimate and recorded. 
Thus, survival seems to be closely linked to immune ontogeny, which is not surprising as it is well established that during development, innate immunity provides quick protection against the hostile environment [6]. Obviously, the study of gene expression can only give an indication of functionality and hence these findings should be confirmed in the future through studies of immune organ development and pathogen challenge experiments. Additionally, the present study only provides a window into the ontogeny of key genes involved in the immune system and future extensive transcriptomic studies will have to be conducted to provide the complete picture. In order to increase survival rates and prevent high and unpredictable mortalities in aquaculture settings, it should thus be investigated if and how the onset of the innate immune system can be shifted earlier towards the time of hatch. Possible mechanisms would include maternal and larval immunostimulation as well as steering larval microbiota $[39,98,99]$.

\subsection{Temperature effects on ontogeny of the immune system}

Temperature is an important factor influencing aquatic life and oviparous fish are directly exposed to it since early ontogeny. This study therefore did not only aim to elucidate some aspects of the European eel's development of the immune system but also how this is influenced by the ambient temperature. Together, this can provide insights into larval physiology, compulsory to defining optimal rearing conditions of European eel in aquaculture as well as identifying potential effects of global warming.

In the present study, immune gene expression was studied until larvae reached the firstfeeding stage, where temperature influenced the age at which the larvae reach that developmental stage, i.e. $16 \mathrm{dph}$ at $16^{\circ} \mathrm{C}, 12 \mathrm{dph}$ at $18^{\circ} \mathrm{C}, 10 \mathrm{dph}$ at $20^{\circ} \mathrm{C}$ and $8 \mathrm{dph}$ at $22^{\circ} \mathrm{C}$ [34]. At the lower end of the thermal spectrum $\left(16^{\circ} \mathrm{C}\right)$ immune defences appeared to be impaired as development is delayed and immune protein activity might be reduced [100].

To compensate for the thermal effect on development, we analysed the influence of temperature at specific larval stages as well as on real-time age (at specific dph). Expression of igm as well as of $t l r 2$ was temperature independent. This indicates that immunoglobulin protection against pathogens at hatch and pathogen detection via TLR2 will not be impaired within the thermal window for larvae. Similarly, there was no effect of rearing temperature on interferon regulating factors and interleukin $\beta$. Also, no statistically significant effect of rearing temperature was detected on $c 3$ expression. However, $c 3$ mRNA levels reflected a temperature dependent decrease of yolk- 
sac area (described in [34]). A temperature effect on initial protection especially during temperatures close to the critical thermal maximum (i.e. $\mathrm{CT}_{\max } \geq 22^{\circ}$ ) can therefore not be excluded. Furthermore, the expression of two studied genes (i.e. $m h c 2$, lysc) was temperature dependent. This thermal influence on c-type lysozyme was surprising as especially innate immune parameters are seen as relatively temperature independent [101]. Immune-related gene expression was particularly affected at $22^{\circ} \mathrm{C}$, which is close to the upper thermal limit of these larvae [34]. The observed overshoot of immune-related gene expression at $22^{\circ} \mathrm{C}$ at the first-feeding stage $(8 \mathrm{dph})$ correlates with an increased expression of heat shock proteins 70 and 90 in the same larvae [34]. This is an indication of temperature induced cellular stress and an immune response towards damaged cells [102]. Protection against pathogens is thus probably impaired at temperatures close to the critical thermal maximum $\left(\mathrm{CT}_{\max }\right)$, which in culture under sub-optimal rearing schemes can be crucial to survival, while in nature heat waves and rising sea surface temperatures could increase larval mortality and hence negatively impact glass eel recruitment.

To summarize, this study provides new molecular tools to study the immune system of eels in response to internal and external factors. Immune-related genes were shown to be influenced by developmental age, the environmental temperature, as well as the associated interactions. In conclusion, the observed ontogeny of the immune response has to be taken into account to optimise rearing conditions and disease prevention protocols (e.g. timing of vaccination, immunostimulation treatments) of $A$. anguilla in culture as it is linked to protection against pathogens and larval survival.

\section{Acknowledgments:}

We thank Peter Lauesen, Maria Krüger-Johnsen and Christian Graver, for assistance in fish husbandry and breeding, as well as Dr. Sune R. Sørensen, Johanna S. Kottmann and Helene Rønquist Knutsen for their support during larval experiments. JJM is indebted to Professor Thorsten Reusch and Dr. Catriona Clemmesen-Bockelmann for giving her the freedom to explore her interests and built her career whilst working at GEOMAR. 


\section{Footnotes}

\section{Data availability}

The data for this study is archived in the repository Mendeley Data following best practices [103] and is available under doi:10.17632/zdpj5vg3xv.1.

\section{Competing interests}

The authors declare that they have no competing or financial interests.

\section{Author's contribution}

Conceived, designed and carried out the tissue expression study: JJM. Conceived, designed and carried out the AngHV-1 infection study: MA. Conceived and designed the larval experiments: SNP, IAEB, JT. Primary funding acquisition: JT, IAEB. Provided eggs for the experiment, JT, IAEB. Performed the larval experiments: SNP, IAEB. Resources for the experimental work: JT, IAEB. Contributed reagents/materials/analysis tools: JJM, IAEB, JT. Performed molecular analysis: JJM, SNP. Analysed the data: JJM, SNP, IAEB. Writing - original draft preparation: JJM and SNP. Writing - Review and editing: MA, IAEB and JT. All authors gave final approval for publication.

\section{Funding}

This study was most notably funded by the Innovation Fund Denmark under grant agreements no. 5184-00093B (EEL-HATCH) and 7076-00125B (ITS-EEL). JJM and the molecular analysis was funded by the European Regional Development Fund Grant no. 12212001 (FINEAQUA). SNP received two travel grants from the Food and Agriculture COST Action FA1205 (AQUAGAMETE). Additionally, financial support for IAEB was provided by the USDA National Institute of Food and Agriculture, Hatch project 1013854.

\section{References:}

[1] W.N. Eschmeyer, R. Fricke, R. van der Laan, Catalog of Fishes: General, Species, References., (2017). http://researcharchive.calacademy.org/research/ichthyology/catalog/fishcatmain.asp). (accessed August 1, 2017). 
[2] M. Dahlberg, Review of survival rates of fish eggs and larvae in relation to impact assessments, Mar. Fish. Rev. 41 (1979) 1-12.

[3] E.D. Houde, Emerging from Hjort's Shadow, J. Northwest Atl. Fish. Sci. 41 (2008) 53-70. doi:10.2960/J.v41.m634.

[4] D. Jacoby, M. Gollock, Anguilla anguilla. The IUCN Red List of Threatened Species 2014: e.T60344A45833138, (2014). doi:10.2305/IUCN.UK.2014-1.RLTS.T60344A45833138.en.

[5] C. Uribe, H. Folch, R. Enriquez, G. Moran, Innate and adaptive immunity in teleost fish: a review, Vet. Med. (Praha). 56 (2011) 486-503.

[6] O. Vadstein, Ø. Bergh, F.-J. Gatesoupe, J. Galindo-Villegas, V. Mulero, S. Picchietti, G. Scapigliati, P. Makridis, Y. Olsen, K. Dierckens, T. Defoirdt, N. Boon, P. De Schryver, P. Bossier, Microbiology and immunology of fish larvae, Rev. Aquac. 5 (2013) S1-S25. doi:10.1111/j.1753-5131.2012.01082.x.

[7] B. Magnadóttir, S. Lange, A. Steinarsson, S. Gudmundsdóttir, The ontogenic development of innate immune parameters of cod (Gadus morhua L.), Comp. Biochem. Physiol. B Biochem. Mol. Biol. 139 (2004) 217-224. doi:10.1016/j.cbpc.2004.07.009.

[8] S. Ferraresso, A. Bonaldo, L. Parma, F. Buonocore, G. Scapigliati, P.P. Gatta, L. Bargelloni, Ontogenetic onset of immune-relevant genes in the common sole (Solea solea), Fish Shellfish Immunol. 57 (2016) 278-292. doi:10.1016/j.fsi.2016.08.044.

[9] B. Kullmann, M. Adamek, D. Steinhagen, R. Thiel, Anthropogenic spreading of anguillid herpesvirus 1 by stocking of infected farmed European eels, Anguilla anguilla (L.), in the Schlei fjord in northern Germany, J. Fish Dis. 40 (2017) 1695-1706. doi:10.1111/jfd.12637.

[10] ICES, ICES report of the Joint EIFAAC/ICES/GFCM. Working Group on Eel (WGEEL), Antalya, Turkey, 2016.

[11] I.A.E. Butts, S.R. Sørensen, S.N. Politis, T.E. Pitcher, J. Tomkiewicz, Standardization of fertilization protocols for the European eel, Anguilla anguilla, Aquaculture. 426-427 (2014) 9-13. doi:10.1016/j.aquaculture.2014.01.020.

[12] S.R. Sørensen, J. Tomkiewicz, P. Munk, I.A.E. Butts, A. Nielsen, P. Lauesen, C. Graver, Ontogeny and growth of early life stages of captive-bred European eel, Aquaculture. 456 (2016) 50-61. doi:10.1016/j.aquaculture.2016.01.015.

[13] I.A.E. Butts, S.R. Sørensen, S.N. Politis, J. Tomkiewicz, First-feeding by European eel larvae: A step towards closing the life cycle in captivity, Aquaculture. 464 (2016) 451-458. doi:10.1016/j.aquaculture.2016.07.028.

[14] J.H.S. Blaxter, The effect of temperature on larval fishes, Neth. J. Zool. 42 (1991) 336-357. doi:10.1163/156854291X00379.

[15] S.N. Politis, F.T. Dahlke, I.A.E. Butts, M.A. Peck, E.A. Trippel, Temperature, paternity and asynchronous hatching influence early developmental characteristics of larval Atlantic cod, Gadus morhua, J. Exp. Mar. Biol. Ecol. 459 (2014) 70-79. doi:10.1016/j.jembe.2014.05.020.

[16] H.O. Pörtner, M.A. Peck, Climate change effects on fishes and fisheries: towards a causeand-effect understanding, J. Fish Biol. 77 (2010) 1745-1779. doi:10.1111/j.10958649.2010.02783.x.

[17] M.I. O’Connor, J.F. Bruno, S.D. Gaines, B.S. Halpern, S.E. Lester, B.P. Kinlan, J.M. Weiss, Temperature control of larval dispersal and the implications for marine ecology, evolution, and conservation, Proc. Natl. Acad. Sci. 104 (2007) 1266-1271. doi:10.1073/pnas.0603422104.

[18] H.O. Pörtner, A.P. Farrell, Physiology and climate change, Science. 322 (2008) 690-692. doi:10.1126/science.1163156.

[19] T.J. Bowden, Modulation of the immune system of fish by their environment, Fish Shellfish Immunol. 25 (2008) 373-383. doi:10.1016/j.fsi.2008.03.017. 
[20] S. Dios, A. Romero, R. Chamorro, A. Figueras, B. Novoa, Effect of the temperature during antiviral immune response ontogeny in teleosts, Fish Shellfish Immunol. 29 (2010) 10191027. doi:10.1016/j.fsi.2010.08.006.

[21] S. Bonhommeau, E. Chassot, E. Rivot, Fluctuations in European eel (Anguilla anguilla) recruitment resulting from environmental changes in the Sargasso Sea, Fish. Oceanogr. 17 (2008) 32-44. doi:10.1111/j.1365-2419.2007.00453.x.

[22] K.D. Friedland, M.J. Miller, B. Knights, Oceanic changes in the Sargasso Sea and declines in recruitment of the European eel, ICES J. Mar. Sci. J. Cons. 64 (2007) 519-530. doi:10.1093/icesjms/fsm022.

[23] J.-N. Chen, J.A. López, S. Lavoué, M. Miya, W.-J. Chen, Phylogeny of the Elopomorpha (Teleostei): Evidence from six nuclear and mitochondrial markers, Mol. Phylogenet. Evol. 70 (2014) 152-161. doi:10.1016/j.ympev.2013.09.002.

[24] M.E. Nielsen, J.J. Miest, J.G. Schmidt, The Immune System, in: Eel Physiol., Taylor \& Francis, 2013.

[25] Y. Suzuki, T. Otake, Skin lectin and the lymphoid tissues in the leptocephalus larvae of the Japanese eel Anguilla japonica, Fish. Sci. 66 (2000) 636-643. doi:10.1046/j.14442906.2000.00104.x.

[26] M.C.H. Holland, J.D. Lambris, The complement system in teleosts, Fish Shellfish Immunol. 12 (2002) 399-420. doi:10.1006/fsim.2001.0408.

[27] R. Savan, M. Sakai, Genomics of fish cytokines, Comp. Biochem. Physiol. Part D Genomics Proteomics. 1 (2006) 89-101. doi:10.1016/j.cbd.2005.08.005.

[28] K. Murphy, P. Travers, M. Walport, C. Janeway, Janeway's immunobiology, Garland Science, New York, 2012.

[29] B. Huang, W.S. Huang, P. Nie, Cloning and expression analyses of interferon regulatory factor (IRF) 3 and 7 genes in European eel, Anguilla anguilla with the identification of genes involved in IFN production, Fish Shellfish Immunol. 37 (2014) 239-247. doi:10.1016/j.fsi.2014.02.009.

[30] A. Callol, N. Roher, C. Amaro, S. MacKenzie, Characterization of PAMP/PRR interactions in European eel (Anguilla anguilla) macrophage-like primary cell cultures, Fish Shellfish Immunol. 35 (2013) 1216-1223. doi:10.1016/j.fsi.2013.07.037.

[31] J. Armitage, N.R. Hewlett, M. Twigg, N.C. Lewin, A.J. Reading, C.F. Williams, M. Aprahamian, K. Way, S.W. Feist, E.J. Peeler, Detection of Herpesvirus anguillae during two mortality investigations of wild European eel in England: implications for fishery management, Fish. Manag. Ecol. 21 (2014) 1-12. doi:10.1111/fme.12039.

[32] M. Sano, H. Fukuda, T. Sano, Isolation and characterisation of a new herpesvirus from eel, in: F.O. Perkins, T.C. Cheng (Eds.), Pathol. Mar. Sci., Academic Press, San Diego, 1990: pp. 15-31. doi:10.1016/B978-0-12-550755-4.50008-2.

[33] K.J. Livak, T.D. Schmittgen, Analysis of relative gene expression data using real-time quantitative PCR and the 2(T)(-Delta Delta C) method, Methods. 25 (2001) 402-408. doi:10.1006/meth.2001.1262.

[34] S.N. Politis, D. Mazurais, A. Servilli, J.L.Z. Infante, J.J. Miest, S.R. Sørensen, J. Tomkiewicz, I.A.E. Butts, Temperature effects on gene expression and morphological development of European eel, Anguilla anguilla larvae, PLOS ONE. 12 (2017) e0182726. doi:https://doi.org/10.1371/journal.pone.0182726.

[35] S.R. Sørensen, P.V. Skov, P. Lauesen, J. Tomkiewicz, P. Bossier, P. De Schryver, Microbial interference and potential control in culture of European eel (Anguilla anguilla) embryos and larvae, Aquaculture. 426-427 (2014) 1-8. doi:10.1016/j.aquaculture.2014.01.011. 
[36] S.N. Politis, I.A.E. Butts, J. Tomkiewicz, Light impacts embryonic and early larval development of the European eel, Anguilla anguilla, J. Exp. Mar. Biol. Ecol. 461 (2014) 407-415. doi:10.1016/j.jembe.2014.09.014.

[37] S.N. Politis, A. Servili, D. Mazurais, J.-L. Zambonino-Infante, J.J. Miest, J. Tomkiewicz, I.A.E. Butts, Temperature induced variation in gene expression of thyroid hormone receptors and deiodinases of European eel (Anguilla anguilla) larvae, Gen. Comp. Endocrinol. 259 (2018) 54-65. doi:10.1016/j.ygcen.2017.11.003.

[38] C.V. Henkel, R.P. Dirks, D.L. de Wijze, Y. Minegishi, J. Aoyama, H.J. Jansen, B. Turner, B. Knudsen, M. Bundgaard, K.L. Hvam, M. Boetzer, W. Pirovano, F.-A. Weltzien, S. Dufour, K. Tsukamoto, H.P. Spaink, G.E.E.J.M. van den Thillart, First draft genome sequence of the Japanese eel, Anguilla japonica, Gene. 511 (2012) 195-201. doi:10.1016/j.gene.2012.09.064.

[39] J.J. Miest, C. Arndt, M. Adamek, D. Steinhagen, T.B.H. Reusch, Dietary $\beta$-glucan (MacroGard ${ }^{\circledR}$ ) enhances survival of first feeding turbot (Scophthalmus maximus) larvae by altering immunity, metabolism and microbiota, Fish Shellfish Immunol. 48 (2016) 94-104. doi:10.1016/j.fsi.2015.11.013.

[40] J. Hellemans, G. Mortier, A. De Paepe, F. Speleman, J. Vandesompele, qBase relative quantification framework and software for management and automated analysis of real-time quantitative PCR data, Genome Biol. 8 (2007) R19. doi:10.1186/gb-2007-8-2-r19.

[41] R. Littel, G. Milliken, W. Stroup, R. Wolfinger, SAS system for mixed models. SAS Institute, Inc Cary NC. (1996).

[42] J.H. McDonald, Handbook of biological statistics, Sparky House Publishing, Baltimore, Maryland, 2009.

[43] B. Magnadottir, S. Gudmundsdottir, B.K. Gudmundsdottir, S. Helgason, Natural antibodies of cod (Gadus morhua L.): Specificity, activity and affinity, Comp. Biochem. Physiol. B Biochem. Mol. Biol. 154 (2009) 309-316. doi:10.1016/j.cbpb.2009.07.005.

[44] M. Samanta, B. Swain, M. Basu, P. Panda, G.B. Mohapatra, B.R. Sahoo, N.K. Maiti, Molecular characterization of toll-like receptor 2 (TLR2), analysis of its inductive expression and associated down-stream signaling molecules following ligands exposure and bacterial infection in the Indian major carp, rohu (Labeo rohita), Fish Shellfish Immunol. 32 (2012) 411-425. doi:10.1016/j.fsi.2011.11.029.

[45] H.B.T. Huttenhuis, C.P.O. Grou, A.J. Taverne-Thiele, N. Taverne, J.H.W.M. Rombout, Carp (Cyprinus carpio L.) innate immune factors are present before hatching, Fish Shellfish Immunol. 20 (2006) 586-596. doi:10.1016/j.fsi.2005.07.008.

[46] J. Mishra, P.K. Sahoo, B.R. Mohanty, A. Das, Sequence information, ontogeny and tissuespecific expression of complement component C3 in Indian major carp, Labeo rohita (Hamilton), Indian J. Exp. Biol. 47 (2009) 672-678.

[47] Z.-H. Qi, Y.-F. Liu, W.-N. Wang, X. Wu, Y. Xin, Y.-F. Lu, A.-L. Wang, Molecular characterization and functional analysis of a complement C3 molecule in the orange-spotted grouper (Epinephelus coioides), Fish Shellfish Immunol. 31 (2011) 1284-1290. doi:10.1016/j.fsi.2011.09.018.

[48] H. Wang, P. Qi, B. Guo, J. li, J. He, C. Wu, Y. Gul, Molecular characterization and expression analysis of a complement component C3 in large yellow croaker (Larimichthys crocea), Fish Shellfish Immunol. 42 (2015) 272-279. doi:10.1016/j.fsi.2014.11.006.

[49] J. Lu, B.K. Teh, L. Wang, Y. Wang, Y.S. Tan, M.C. Lai, K.B.M. Reid, The classical and regulatory functions of C1q in immunity and autoimmunity, Cell. Mol. Immunol. 5 (2008) 921. doi:10.1038/cmi.2008.2.

[50] C. Fan, J. Wang, X. Zhang, J. Song, Functional C1q is present in the skin mucus of Siberian sturgeon (Acipenser baerii), Integr. Zool. 10 (2015) 102-110. 
[51] Y.-L. Hu, X.-M. Pan, L.-X. Xiang, J.-Z. Shao, Characterization of C1q in Teleosts insight into the molecular and functional evolution of C1q family and classical pathway, J. Biol. Chem. 285 (2010) 28777-28786. doi:10.1074/jbc.M110.131318.

[52] H.-H. Lao, Y.-N. Sun, Z.-X. Yin, J. Wang, C. Chen, S.-P. Weng, W. He, C.-J. Guo, X.-D. Huang, X.-Q. Yu, J.-G. He, Molecular cloning of two C1q-like cDNAs in mandarin fish Siniperca chuatsi, Vet. Immunol. Immunopathol. 125 (2008) 37-46. doi:10.1016/j.vetimm.2008.05.004.

[53] N. Pionnier, M. Adamek, J. Miest, S. Harris, M. Matras, K. Rakus, I. Irnazarow, D. Hoole, Creactive protein and complement as acute phase reactants in common carp Cyprinus carpio during CyHV-3 infection, Dis. Aquat. Organ. 109 (2014) 187-199. doi:10.3354/dao02727.

[54] F.L. Rock, G. Hardiman, J.C. Timans, R.A. Kastelein, J.F. Bazan, A family of human receptors structurally related to Drosophila Toll, Proc. Natl. Acad. Sci. U. S. A. 95 (1998) 588-593. doi:10.1073/pnas.95.2.588.

[55] I. Hirono, M. Takami, M. Miyata, T. Miyazaki, H.-J. Han, T. Takano, M. Endo, T. Aoki, Characterization of gene structure and expression of two toll-like receptors from Japanese flounder, Paralichthys olivaceus, Immunogenetics. 56 (2004) 38-46. doi:10.1007/s00251004-0657-2.

[56] C. Jault, L. Pichon, J. Chluba, Toll-like receptor gene family and TIR-domain adapters in Danio rerio, Mol. Immunol. 40 (2004) 759-771. doi:10.1016/j.molimm.2003.10.001.

[57] Y.C. Wei, T.S. Pan, M.X. Chang, B. Huang, Z. Xu, T.R. Luo, P. Nie, Cloning and expression of Toll-like receptors 1 and 2 from a teleost fish, the orange-spotted grouper Epinephelus coioides, Vet. Immunol. Immunopathol. 141 (2011) 173-182. doi:10.1016/j.vetimm.2011.02.016.

[58] F. Buonocore, E. Randelli, S. Bird, C.J. Secombes, A. Facchiano, S. Costantini, G. Scapigliati, Interleukin-10 expression by real-time PCR and homology modelling analysis in the European sea bass (Dicentrarchus labrax L.), Aquaculture. 270 (2007) 512-522. doi:10.1016/j.aquaculture.2007.05.040.

[59] R. Savan, D. Igawa, M. Sakai, Cloning, characterization and expression analysis of interleukin-10 from the common carp, Cyprinus carpio L., Eur. J. Biochem. 270 (2003) 4647-4654. doi:10.1046/j.1432-1033.2003.03854.x.

[60] S. Cecchini, M. Paciolla, E. Biffali, M. Borra, M.V. Ursini, M.B. Lioi, Ontogenetic profile of innate immune related genes and their tissue-specific expression in brown trout, Salmo trutta (Linnaeus, 1758), Fish Shellfish Immunol. 35 (2013) 988-992. doi:10.1016/j.fsi.2013.05.026.

[61] P. Dash, S. Patel, A. Dixit, L.C. Garg, P.K. Sahoo, Four pro-inflammatory cytokines of rohu (Labeo rohita) during early developmental stages, their tissue distribution and expression by leucocytes upon in-vitro stimulation, Fish Shellfish Immunol. 47 (2015) 913-922. doi:10.1016/j.fsi.2015.10.034.

[62] M. Angeles Esteban, An overview of the immunological defenses in fish skin, Int. Sch. Res. Not. 2012 (2012) 853470. doi:10.5402/2012/853470, 10.5402/2012/853470.

[63] F.-W. Tesch, The Eel: Biology and management of Anguillid eels, Springer Netherlands, Dordrecht, 2011. doi:10.1007/978-94-009-5761-9.

[64] M. Adamek, H. Syakuri, S. Harris, K.Ł. Rakus, G. Brogden, M. Matras, I. Irnazarow, D. Steinhagen, Cyprinid herpesvirus 3 infection disrupts the skin barrier of common carp (Cyprinus carpio L.), Vet. Microbiol. 162 (2013) 456-470. doi:10.1016/j.vetmic.2012.10.033.

[65] K.J. Laing, T. Wang, J. Zou, J. Holland, S. Hong, N. Bols, I. Hirono, T. Aoki, C.J. Secombes, Cloning and expression analysis of rainbow trout Oncorhynchus mykiss tumour necrosis factor- $\alpha$, Eur. J. Biochem. 268 (2001) 1315-1322. doi:10.1046/j.1432-1327.2001.01996.x. 
[66] S. Hong, R. Li, Q. Xu, C.J. Secombes, T. Wang, Two types of TNF- $\alpha$ exist in teleost fish: Phylogeny, expression, and bioactivity analysis of Type-II TNF- $\alpha 3$ in Rainbow Trout Oncorhynchus mykiss, J. Immunol. 191 (2013) 5959-5972. doi:10.4049/jimmunol.1301584.

[67] R.A. Kajungiro, L. Xue, M. Aynealem, Molecular cloning and expression patterns of two tumor necrosis factor alpha genes in crucian carp (Carassius carassius, Mol. Biol. 49 (2015) 120-129. doi:10.1134/S0026893315010021.

[68] J. Xiao, Z.-C. Zhou, C. Chen, W.-L. Huo, Z.-X. Yin, S.-P. Weng, S.-M. Chan, X.-Q. Yu, J.G. He, Tumor necrosis factor-alpha gene from mandarin fish, Siniperca chuatsi: Molecular cloning, cytotoxicity analysis and expression profile, Mol. Immunol. 44 (2007) 3615-3622. doi:10.1016/j.molimm.2007.03.016.

[69] W.C. Au, P.A. Moore, W. Lowther, Y.T. Juang, P.M. Pitha, Identification of a member of the interferon regulatory factor family that binds to the interferon-stimulated response element and activates expression of interferon-induced genes., Proc. Natl. Acad. Sci. U. S. A. 92 (1995) 11657-11661.

[70] A. Izaguirre, B.J. Barnes, S. Amrute, W.-S. Yeow, N. Megjugorac, J. Dai, D. Feng, E. Chung, P.M. Pitha, P. Fitzgerald-Bocarsly, Comparative analysis of IRF and IFN-alpha expression in human plasmacytoid and monocyte-derived dendritic cells, J. Leukoc. Biol. 74 (2003) 1125-1138. doi:10.1189/jlb.0603255.

[71] M. Adamek, K.Ł. Rakus, J. Chyb, G. Brogden, A. Huebner, I. Irnazarow, D. Steinhagen, Interferon type I responses to virus infections in carp cells: In vitro studies on Cyprinid herpesvirus 3 and Rhabdovirus carpio infections, Fish Shellfish Immunol. 33 (2012) 482493. doi:10.1016/j.fsi.2012.05.031.

[72] G. Hu, X. Yin, J. Xia, X. Dong, J. Zhang, Q. Liu, Molecular cloning and characterization of interferon regulatory factor 7 (IRF-7) in Japanese flounder, Paralichthys olivaceus, Fish Shellfish Immunol. 29 (2010) 963-971. doi:10.1016/j.fsi.2010.08.002.

[73] Y. Zhang, C. Hu, J. Zhang, G. Huang, L. Wei, Q. Zhang, J. Gui, Molecular cloning and characterization of crucian carp (Carassius auratus L.) interferon regulatory factor 71, Fish Shellfish Immunol. 15 (2003) 453-466. doi:10.1016/S1050-4648(03)00025-1.

[74] Y. Gao, Y. Yi, H. Wu, Q. Wang, J. Qu, Y. Zhang, Molecular cloning and characterization of secretory and membrane-bound IgM of turbot, Fish Shellfish Immunol. 40 (2014) 354-361. doi:10.1016/j.fsi.2014.07.011.

[75] N.R. Saha, H. Suetake, Y. Suzuki, Analysis and characterization of the expression of the secretory and membrane forms of IgM heavy chains in the pufferfish, Takifugu rubripes, Mol. Immunol. 42 (2005) 113-124. doi:10.1016/j.molimm.2004.06.034.

[76] C. McArthur, Haematology of the New Zealand freshwater eels Anguilla australis schmidtii and A. dieffenbachii, N. Z. J Zool. 41 (1977) 5-20.

[77] S.K. Whyte, The innate immune response of finfish - A review of current knowledge, Fish Shellfish Immunol. 23 (2007) 1127-1151. doi:10.1016/j.fsi.2007.06.005.

[78] T. Nakanishi, Y. Shibasaki, Y. Matsuura, T Cells in Fish, Biology. 4 (2015) 640-663. doi:10.3390/biology4040640.

[79] W. Li, W. Sun, L. Meng, D. Hong, Molecular cloning, genomic structure, polymorphism and expression analysis of major histocompatibility complex class IIA gene of swamp eel Monopterus albus, Biologia (Bratisl.). 69 (2013) 236-246. doi:10.2478/s11756-013-0307-y.

[80] K.t. Rakus, G.F. Wiegertjes, M. Adamek, A.K. Siwicki, A. Lepa, I. Irnazarow, Resistance of common carp (Cyprinus carpio L.) to Cyprinid herpesvirus-3 is influenced by major histocompatibility (MH) class II B gene polymorphism, Fish Shellfish Immunol. 26 (2009) 737-743. doi:10.1016/j.fsi.2009.03.001. 
[81] M. Adamek, D. Steinhagen, I. Irnazarow, J. Hikima, T.-S. Jung, T. Aoki, Biology and host response to Cyprinid herpesvirus 3 infection in common carp, Dev. Comp. Immunol. 43 (2014) 151-159. doi:10.1016/j.dci.2013.08.015.

[82] A. Castillo, C. Sánchez, J. Dominguez, S.L. Kaattari, A.J. Villena, Ontogeny of IgM and IgM-bearing cells in rainbow trout, Dev. Comp. Immunol. 17 (1993) 419-424. doi:10.1016/0145-305X(93)90033-M.

[83] J.-W. Lee, Y.M. Lee, J.-H. Lee, J.K. Noh, H.C. Kim, C.-J. Park, J.-W. Park, I.J. Hwang, S.Y. Kim, The expression analysis of complement component $\mathrm{C} 3$ during early developmental stages in olive flounder (Paralichthys olivaceus), Dev. Reprod. 17 (2013) 311-319. doi:10.12717/DR.2013.17.4.311.

[84] Y. Olsen, C.M. Press, Degradation kinetics of immunoglobulin in the egg, alevin and fry of Atlantic salmon, Salmo salar L., and the localisation of immunoglobulin in the egg, Fish Shellfish Immunol. 7 (1997) 81-91. doi:10.1006/fsim.1996.0064.

[85] P. Swain, S.K. Nayak, Role of maternally derived immunity in fish, Fish Shellfish Immunol. 27 (2009) 89-99. doi:10.1016/j.fsi.2009.04.008.

[86] G. Breuil, B. Vassiloglou, J.F. Pepin, B. Romestand, Ontogeny of IgM-bearing cells and changes in the immunoglobulin M-like protein level (IgM) during larval stages in sea bass (Dicentrarchus labrax), Fish Shellfish Immunol. 7 (1997) 29-43. doi:10.1006/fsim.1996.0061.

[87] A. Takemura, K. Takano, Transfer of maternally-derived immunoglobulin ( $\operatorname{ggM})$ to larvae in tilapia, Oreochromis mossambicus, Fish Shellfish Immunol. 7 (1997) 355-363. doi:10.1006/fsim.1997.0090.

[88] M. Kawabe, H. Suetake, K. Kikuchi, Y. Suzuki, Early T-cell and thymus development in Japanese eel Anguilla japonica, Fish. Sci. 78 (2012) 539-547. doi:10.1007/s12562-012-04793.

[89] A.Y.M. Sundaram, S. Consuegra, V. Kiron, J.M.O. Fernandes, Positive selection pressure within teleost toll-like receptors tlr21 and tlr22 subfamilies and their response to temperature stress and microbial components in zebrafish, Mol. Biol. Rep. 39 (2012) 8965-8975. doi:10.1007/s11033-012-1765-y.

[90] J.-W. Lee, J.-H. Lee, J.K. Noh, H.C. Kim, C.-J. Park, J.-W. Park, K.-K. Kim, Transcriptional onset of lysozyme genes during early development in olive flounder (Paralichthys olivaceus), Dev. Reprod. 18 (2014) 267-274. doi:10.12717/devrep.2014.18.4.267.

[91] Z. Wang, S. Zhang, The role of lysozyme and complement in the antibacterial activity of zebrafish (Danio rerio) egg cytosol, Fish Shellfish Immunol. 29 (2010) 773-777. doi:10.1016/j.fsi.2010.07.002.

[92] R.C. Chambers, D.A. Witting, S.J. Lewis, Detecting critical periods in larval flatfish populations, J. Sea Res. 45 (2001) 231-242. doi:10.1016/S1385-1101(01)00058-2.

[93] P.K. Hershberger, J. Gregg, C. Pacheco, J. Winton, J. Richard, G. Traxler, Larval Pacific herring, Clupea pallasii (Valenciennes), are highly susceptible to viral haemorrhagic septicaemia and survivors are partially protected after their metamorphosis to juveniles, J. Fish Dis. 30 (2007) 445-458. doi:10.1111/j.1365-2761.2007.00829.x.

[94] M.H. Stiasny, F.H. Mittermayer, M. Sswat, R. Voss, F. Jutfelt, M. Chierici, V. Puvanendran, A. Mortensen, T.B.H. Reusch, C. Clemmesen, Ocean acidification effects on Atlantic cod larval survival and recruitment to the fished population, PLOS ONE. 11 (2016) e0155448. doi:10.1371/journal.pone.0155448.

[95] J. Hjort, Fluctuations in the great fisheries of northern Europe viewed in the light of biological research, in: ICES, 1914. 
[96] N. McCasker, P. Humphries, S. Meredith, N. Klomp, Contrasting Patterns of Larval Mortality in Two Sympatric Riverine Fish Species: A Test of the Critical Period Hypothesis, PLOS ONE. 9 (2014) e109317. doi:10.1371/journal.pone.0109317.

[97] S. Garrido, R. Ben-Hamadou, A.M.P. Santos, S. Ferreira, M.A. Teodósio, U. Cotano, X. Irigoien, M.A. Peck, E. Saiz, P. Ré, Born small, die young: Intrinsic, size-selective mortality in marine larval fish, Sci. Rep. 5 (2015). doi:10.1038/srep17065.

[98] P. De Schryver, O. Vadstein, Ecological theory as a foundation to control pathogenic invasion in aquaculture, ISME J. 8 (2014) 2360-2368. doi:10.1038/ismej.2014.84.

[99] A. Franke, O. Roth, P.D. Schryver, T. Bayer, L. Garcia-Gonzalez, S. Künzel, P. Bossier, J.J. Miest, C. Clemmesen, Poly- $\beta$-hydroxybutyrate administration during early life: effects on performance, immunity and microbial community of European sea bass yolk-sac larvae, Sci. Rep. 7 (2017). doi:10.1038/s41598-017-14785-z.

[100] C.L. Morvan, D. Troutaud, P. Deschaux, Differential effects of temperature on specific and nonspecific immune defences in fish., J. Exp. Biol. 201 (1998) 165-168.

[101] B. Magnadóttir, Innate immunity of fish (overview), Fish Shellfish Immunol. 20 (2006) 137151. doi:10.1016/j.fsi.2004.09.006.

[102] S. Muralidharan, P. Mandrekar, Cellular stress response and innate immune signaling: integrating pathways in host defense and inflammation, J. Leukoc. Biol. 94 (2013) 11671184. doi:10.1189/jlb.0313153.

[103] D.G. Roche, L.E.B. Kruuk, R. Lanfear, S.A. Binning, Public Data Archiving in Ecology and Evolution: How Well Are We Doing?, PLOS Biol. 13 (2015) e1002295.

doi:10.1371/journal.pbio.1002295. 